\title{
Grazing weakens competitive interactions between active methanotrophs and nitrifiers modulating greenhouse-gas emissions in grassland soils
}

\author{
Hong Pan ${ }^{1,2,7}$, Haojie Feng ${ }^{2,7}$, Yaowei Liu ${ }^{1}$, Chun-Yu Lai ${ }^{3}$, Yuping Zhuge ${ }^{2}$, Qichun Zhang ${ }^{1}$, Caixian Tang ${ }^{4}$, Hongjie Di ${ }^{1}$, Zhongjun Jia (iD ${ }^{5}$,

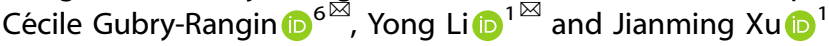

(c) The Author(s) 2021, corrected publication 2022

\begin{abstract}
Grassland soils serve as a biological sink and source of the potent greenhouse gases (GHG) methane $\left(\mathrm{CH}_{4}\right)$ and nitrous oxide $\left(\mathrm{N}_{2} \mathrm{O}\right)$. The underlying mechanisms responsible for those GHG emissions, specifically, the relationships between methane- and ammoniaoxidizing microorganisms in grazed grassland soils are still poorly understood. Here, we characterized the effects of grazing on in situ GHG emissions and elucidated the putative relations between the active microbes involving in methane oxidation and nitrification activity in grassland soils. Grazing significantly decreases $\mathrm{CH}_{4}$ uptake while it increases $\mathrm{N}_{2} \mathrm{O}$ emissions basing on 14month in situ measurement. DNA-based stable isotope probing (SIP) incubation experiment shows that grazing decreases both methane oxidation and nitrification processes and decreases the diversity of active methanotrophs and nitrifiers, and subsequently weakens the putative competition between active methanotrophs and nitrifiers in grassland soils. These results constitute a major advance in our understanding of putative relationships between methane- and ammonia-oxidizing microorganisms and subsequent effects on nitrification and methane oxidation, which contribute to a better prediction and modeling of future balance of GHG emissions and active microbial communities in grazed grassland ecosystems.
\end{abstract}

ISME Communications; https://doi.org/10.1038/s43705-021-00068-2

\section{INTRODUCTION}

Methane $\left(\mathrm{CH}_{4}\right)$, as the second most potent greenhouse gas (GHG) after carbon dioxide $\left(\mathrm{CO}_{2}\right)$, is considered to be responsible for $\sim 20 \%$ of the anthropogenic global warming effect [1]. Its atmospheric concentration has doubled from about $700 \mathrm{ppb}$ at pre-industrial times to the current concentration of $1850.5 \mathrm{ppb}$ [2]. Aerobic oxidation of $\mathrm{CH}_{4}$ in soils by methane-oxidizing bacteria (MOB), also known as methanotrophs, represents the largest biological sink for atmospheric $\mathrm{CH}_{4}$ [3]. Methanotrophs have the unique ability to grow on $\mathrm{CH}_{4}$ as their sole source of carbon and energy. They are ubiquitous in the environment and play a major role in the removal of the greenhouse gas methane from the biosphere before it is released into the atmosphere [4].

The key step of aerobic methane oxidation, the initial oxidation of $\mathrm{CH}_{4}$ to methanol, is catalyzed by the methane monooxygenase which exists either as a particulate, membrane-bound form (pMMO), or a soluble, cytosolic form [5]. It is noticeable that pMMO of MOB and ammonia monooxygenase (AMO) of ammonia-oxidizing bacteria (AOB) are homologous members [6], which are grouped into the copper-containing membrane-bound monooxygenase (CuMMO) family [7]. The AMO of ammonia- oxidizing archaea (AOA) is also a CuMMO, but it is a phylogenetically distant one from those of $M O B$ and $A O B$ [8]. Traditionally, ammonia $\left(\mathrm{NH}_{3}\right)$ was converted into nitrite by $A O A / A O B$ and further oxidized into nitrate by nitrite-oxidizing bacteria (NOB). The evolutionary links between $\mathrm{MOB}$ and $\mathrm{AOB}$, together with the similar molecular structure of their substrates $\left(\mathrm{NH}_{3}\right.$ and $\mathrm{CH}_{4}$, respectively), lead to functional similarities enabling them to oxidize both $\mathrm{NH}_{3}$ and $\mathrm{CH}_{4}$, although neither $\mathrm{AOB}$ nor $\mathrm{MOB}$ are capable of growing on the alternative substrate [9-11].

Methanotrophs and ammonia oxidizers are considered as strong competitors for $\mathrm{N}$ to maintain their growth and activity $[12,13]$. However, response and activity of methanotrophs to $\mathrm{N}$ levels remains unsolved and is still debated. Previous studies either demonstrated that ammonium could stimulate [12, 14-17], suppress $[18,19]$, or exert little impact on $[20,21]$ the global methanotrophic $\mathrm{CH}_{4}$ sink. Therefore, there are some gaps of knowledge concerning the mechanisms controlling the relationships between methane oxidation and $\mathrm{N}$ levels. Additionally, $\mathrm{N}$ levels are particularly important in controlling niche specialization of the ecology and evolution of $A O A$ and $A O B$ [14, 22]. AOA generally dominates ammonia oxidation in $\mathrm{N}$-limited soils while

\footnotetext{
${ }^{1}$ Institute of Soil and Water Resources and Environmental Science, College of Environmental and Resource Sciences, Zhejiang Provincial Key Laboratory of Agricultural Resources and Environment, Zhejiang University, Hangzhou 310058, China. ${ }^{2}$ National Engineering Laboratory for Efficient Utilization of Soil and Fertilizer Resources, College of Resources and Environment, Shandong Agricultural University, Daizong Road, Tai'an City, Shandong 271018, China. ${ }^{3}$ Advanced Water Management Centre, The University of Queensland, St Lucia, QLD 4072, Australia. ${ }^{4}$ Department of Animal, Plant and Soil Sciences, Centre for AgriBioscience, La Trobe University, Bundoora, VIC 3086 , Australia. ${ }^{5}$ State Key Laboratory of Soil and Sustainable Agriculture, Institute of Soil Science, Chinese Academy of Sciences, Nanjing 210008 , China. ${ }^{6}$ School of Biological Sciences, University of Aberdeen, Aberdeen AB24 3UU, UK. ${ }^{7}$ These authors contributed equally: Hong Pan, Haojie Feng. ${ }^{\circledR}$ email: c.rangin@abdn.ac.uk; liyongcn@zju.edu.cn
} 
AOB dominates ammonia oxidation in $\mathrm{N}$-rich environments $[12,14,22]$. It is thus hypothesized that ammonium-assimilating $M O B$ decreases nitrification rate by competing for $N$ with $A O A$ and $A O B$, especially in N-limited soils.

Grasslands are known as important biological sinks of $\mathrm{CH}_{4}$ and sources of $\mathrm{N}_{2} \mathrm{O}$ and grassland soils are often viewed as important ecosystems influencing global environmental change through their strong capacity to produce, store, and cycle $\mathrm{C}$ and $\mathrm{N}$ substrates [23, 24]. It is reported that grassland ecosystems contain more than one-third of above- and below-ground $C$ reserves because grasslands cover nearly half of the Earth's land surface [25]. Notably, management practices of grasslands can alter the exchange of $\mathrm{C}$ and $\mathrm{N}$ between atmosphere and soil, aboveground and belowground biomass. Livestock grazing, for example, is the most important and pervasive practice in grasslands. Increasing stocking rates have been implemented to meet the increasing food demands of a growing population, but grazing modifies $\mathrm{C}$ and $\mathrm{N}$ cycling in grassland soils [26]. Grazing has also been shown to be an important factor regulating the emission and uptake of greenhouse gases [27] with moderatelygrazed grassland having high $\mathrm{CH}_{4}$ uptake, while heavy grazing suppresses soil $\mathrm{CH}_{4}$ uptake and stimulates $\mathrm{N}_{2} \mathrm{O}$ emissions $[28,29]$. Analysis of the active methanotrophs in such ecosystems has shown that grazing decreases the abundance and diversity of the active methanotrophs in steppe soils [30]. Grazing also significantly decreases nitrification activity, and different grazing intensity leads to diverse active communities with $A O A$ and $A O B$ dominating nitrification in lightly- and heavily-grazed soils, respectively [31]. However, previous studies have primarily focused on effects of grazing on nitrification or methane oxidation, but very little is known about their relationships in grassland ecosystem as well as the responsible microbial communities.

In this study, we firstly investigated in situ greenhouse gas emissions in ungrazed and grazed grasslands for 14-months (August 2014 to October 2015) using closed static chambers. Then a controlled incubation experiment was conducted in the laboratory to understand microbial relationships modulating greenhouse gas emissions in grassland by performing DNA-SIP and Illumina HiSeq $16 \mathrm{~S}$ ribosomal RNA (rRNA) gene sequencing. The present study aimed to (1) characterize the impact of longterm grazing on active methanotrophs and nitrifiers, (2) examine the mechanisms underlying the effects of $\mathrm{N}$ level on $\mathrm{CH}_{4}$ and $\mathrm{NH}_{3}$ oxidation, and (3) clarify the relationships occurring between important players of the methane and ammonia oxidation in grazed grassland soils. We hypothesized that grazing would suppress the competitions between methane- and ammoniaoxidizing microorganisms by decreasing their diversities and activities. Elucidating these putative relationships is crucial for understanding the methane-nitrogen cycling and its effects on global climate change.

\section{MATERIALS AND METHODS}

\section{Site description and soil sampling}

The experimental site was situated at the Inner Mongolia Grassland Ecosystem Research Station (IMGERS, $43^{\circ} 37^{\prime} \mathrm{N}, 116^{\circ} 43^{\prime} \mathrm{E}$ ) on the Xilingol steppe of the Xilin River basin, bounded by the west side of the Daxing-An Mountain. This ecoregion possesses a semi-arid continental climate with mean annual temperature of $-0.4{ }^{\circ} \mathrm{C}$, and $348 \mathrm{~mm}$ of precipitation which was distributed unevenly across the seasons, falling mostly during June-August. The vegetation type was Leymus chinensis with some Stipa grandis and Cleistogenes squarrosa. The soil was classified as Calcic Chernozem according to ISSS Working Group RB, 1998.

Two adjacent long-term field plots were established at the Research Station, one ungrazed and enclosed since 1983 ("Ungrazed") and the other subjected to free grazing ("Grazed"). Both sites were derived from a paddock that had uniform fertility and slope. At each site, a transect of 60 $m \times 400 m$ was established with five equal-sized replicate plots of dimension $60 \mathrm{~m} \times 70 \mathrm{~m}$. A 10-m-wide buffer strip was established between every plot to avoid interactions and allow for sampling. Soil samples were collected from the upper 10-cm layer from five random locations within each plot following an "S" sampling pattern using a $5-\mathrm{cm}$ diameter soil auger in August 2016. The five samples from each plot were grouped into a single composite sample, packed with ice packs, and transported to the laboratory. Soil samples were then passed through a $2-\mathrm{mm}$ sieve. Subsamples were air-dried for physicochemical analysis. The remaining fresh soils were used for the incubation experiment.

Soil $\mathrm{pH}$ was measured using a pH meter (Mettler-Toledo, Switzerland) after shaking the soil at a soil-water ratio of 1:2.5. Gravimetric soil moisture content was analyzed by oven-drying at $105 \pm 2{ }^{\circ} \mathrm{C}$ for $24 \mathrm{~h}$. Soil bulk density was measured by the volumetric ring method according to Lampurlanés and Cantero-Martinez [32]. Soil organic matter was determined by dichromate digestion [33]. Total $\mathrm{C}$ and $\mathrm{N}$ were determined by dry combustion in a Vario Max CNS analyzer (Elementar Instrument, Mt. Laurel, $\mathrm{NJ})$. Olsen $\mathrm{P}$ was extracted by $0.5 \mathrm{M} \mathrm{NaHCO}_{3}(\mathrm{pH}=8.5)$ for $0.5 \mathrm{~h}$ and determined with the molybdenum blue method [34]. Available potassium was extracted by $1 \mathrm{M}$ ammonium acetate and determined by flame emission spectrophotometry. Exchangeable $\mathrm{NH}_{4}{ }^{+}$and $\mathrm{NO}_{3}{ }^{-}$were extracted with $1 \mathrm{M} \mathrm{KCl}$ for $1 \mathrm{~h}$ and determined by a flow injection analyzer (SAN++, Skalar, Holland).

\section{In situ $\mathrm{CH}_{4}$ and $\mathrm{N}_{2} \mathrm{O}$ measurements}

To elucidate the effects of grazing on $\mathrm{N}_{2} \mathrm{O}$ and $\mathrm{CH}_{4}$ emissions from grassland soils, we collected gas samples using closed-chamber greenhouse gas-flux method from August 2014 to October 2015. For gas sampling, a static chamber $(50 \mathrm{~cm}$ diameter) was installed in each of the five replicated plots into the ungrazed and grazed soils (in close proximity to the soil sampling points) resulting in ten chambers. Gas samples $(40 \mathrm{ml})$ were collected five times during the in-situ field study, in May (early pasture-growing season, 2015 only), August (peak pasture-growing season), and October (non-growing season) in both 2014 and 2015. Gas samples were collected 0 and $40 \mathrm{~min}$ after chamber closure using a $20-\mathrm{ml}$ syringe and injected into preevacuated $20-\mathrm{ml}$ glass bottles and samples were collected between 10 and 12 a.m. The concentrations of $\mathrm{N}_{2} \mathrm{O}$ and $\mathrm{CH}_{4}$ in gas samples were analyzed using a gas chromatograph (Shimadzu GC2010 Plus, Japan).

\section{Construction and sampling of soil microcosms}

Fresh soil (equivalent to $6.0 \mathrm{~g}$ dry weight) was pre-incubated at $40 \%$ field moisture capacity in a $120-\mathrm{ml}$ serum bottle for ten days at $25^{\circ} \mathrm{C}$ in darkness before the incubation experiment. Microcosms were established using seven treatments (each in triplicate, see details in Table $\mathrm{S} 1$ including (i) ${ }^{13} \mathrm{C}^{-} \mathrm{CH}_{4}$ without urea addition $\left(\mathrm{UO}+{ }^{13} \mathrm{CH}_{4}\right)$; (ii) Low ${ }^{13} \mathrm{C}$-urea with ${ }^{13} \mathrm{C}^{-} \mathrm{CO}_{2}$ (U2O $+{ }^{13} \mathrm{CO}_{2}$, corresponding to $20 \mathrm{mg}{ }^{13} \mathrm{C}$-urea- $\mathrm{N} \mathrm{kg}{ }^{-1}$ soil); (iii) High ${ }^{13} \mathrm{C}$-urea with ${ }^{13} \mathrm{C}^{-\mathrm{CO}_{2}}$ (U100 $+{ }^{13} \mathrm{CO}_{2}$, corresponding to $100 \mathrm{mg}{ }^{13} \mathrm{C}$-urea-N $\mathrm{kg}^{-1}$ soil); (iv) Low ${ }^{13} \mathrm{C}$-urea with ${ }^{13} \mathrm{C}-\mathrm{CO}_{2}$ and ${ }^{13} \mathrm{C}_{-} \mathrm{CH}_{4}\left(\mathrm{U} 2 \mathrm{O}+{ }^{13} \mathrm{CO}_{2}+{ }^{13} \mathrm{CH}_{4}\right)$; (v) High ${ }^{13} \mathrm{C}$-urea with ${ }^{13} \mathrm{C}-\mathrm{CO}_{2}$ and ${ }^{13} \mathrm{C}^{-} \mathrm{CH}_{4}\left(\mathrm{U} 100+{ }^{13} \mathrm{CO}_{2}+{ }^{13} \mathrm{CH}_{4}\right)$; (vi) Low ${ }^{12} \mathrm{C}$-urea with ${ }^{12} \mathrm{C}-\mathrm{CO}_{2}$ and ${ }^{12} \mathrm{C}_{-} \mathrm{CH}_{4}\left(\mathrm{U} 2 \mathrm{O}+{ }^{12} \mathrm{CO}_{2}+{ }^{12} \mathrm{CH}_{4}\right)$; (vii) High ${ }^{12} \mathrm{C}$-urea with ${ }^{12} \mathrm{C}-\mathrm{CO}_{2}$ and ${ }^{12} \mathrm{C}-\mathrm{CH}_{4}\left(\mathrm{U} 100+{ }^{12} \mathrm{CO}_{2}+{ }^{12} \mathrm{CH}_{4}\right)$. The microcosms supplemented with ${ }^{13} \mathrm{C}-\mathrm{CH}_{4}$ or ${ }^{13} \mathrm{C}$-urea microcosms were used to monitor the active methanotrophs and nitrifiers, respectively, while the microcosms supplemented with ${ }^{13} \mathrm{C}$-urea and ${ }^{13} \mathrm{C}-\mathrm{CH}_{4}$ were used to monitor the putative relationships between active methanotrophs and nitrifiers. The application rate of U20 was to mimic the annual total $\mathrm{N}$ deposition in the grassland ecosystems. The annual total inorganic $\mathrm{N}$ deposition to Inner Mongolia grassland regions ranged from 4 to $20 \mathrm{~kg} \mathrm{Nha}^{-1}$ year $^{-1}$ [35], which is equivalent to $3-15 \mathrm{mg} \mathrm{N} \mathrm{kg}^{-1}$ dry soil, assuming an effective soil depth of 15 $\mathrm{cm}$. The treatment of $\mathrm{U} 100$ was implemented to simulate $\mathrm{N}$ input accompanied with livestock excrements, as up to $300 \mathrm{~kg} \mathrm{~N} \mathrm{ha}^{-1} \mathrm{y}^{-1}$ can be returned to grassland soils in the form of livestock urine [36]. Urea was added weekly by dropwise addition of freshly made urea solution, as degradation of urea into $\mathrm{NH}_{4}^{+}-\mathrm{N}$ would occur very quickly in soils, to achieve $60 \%$ field capacity to establish a substrate-rich environment for nitrifying communities. For the $\mathrm{UO}+{ }^{13} \mathrm{CH}_{4}$ treatment, distilled water was added instead of urea solution to achieve the $60 \%$ field capacity. Microcosms were flushed before any supplementation of urea or methane with synthetic air $\left(20 \% \mathrm{O}_{2}, 80 \% \mathrm{~N}_{2}\right)$ for $1 \mathrm{~min}$ to maintain oxic conditions. The bottles were then sealed with rubber stoppers and aluminum caps and $5 \%$ and $1 \%(\mathrm{v} / \mathrm{v})$ of labeled or unlabeled $\mathrm{CO}_{2}$ and $\mathrm{CH}_{4}$ were injected into each corresponding microcosm through the rubber septum. The unlabeled and labeled urea and $\mathrm{CO}_{2}(99$ atom $\%{ }^{13} \mathrm{C}$ ) were purchased from the Shanghai Engineering Research Center of Stable Isotopes (Shanghai, China). The unlabeled and labeled $\mathrm{CH}_{4}$ (99 atom 
$\%{ }^{13} \mathrm{C}$ ) were purchased from Sigma-Aldrich (St Louis, MO, USA). The microcosms were incubated at $25^{\circ} \mathrm{C}$ in the dark for 21 days. For the ${ }^{13} \mathrm{CH}_{4}$ microcosms, the concentrations of $\mathrm{CH}_{4}$ were measured daily by gas chromatography (Shimadzu GC-2010 Plus, Japan), and ${ }^{13} \mathrm{CH}_{4}$ or ${ }^{12} \mathrm{CH}_{4}$ was then renewed to maintain $1 \% \mathrm{CH}_{4}$ in the microcosms. The measurement time and dynamic consumption of $\mathrm{CH}_{4}$ are detailed in Table S2 and Fig. S1. The methane oxidation activity was assessed by measuring the amount of methane oxidized over the 21-day incubation time. Initial soil samples (day 0) were collected immediately after the 10-day pre-incubation and urea addition. Destructive sampling was carried out at 7, 14, and 21 days. About $2 \mathrm{~g}$ of soil was sampled from each triplicate microcosm and transferred immediately to a $-80^{\circ} \mathrm{C}$ freezer for later molecular analysis. Soil $\mathrm{NO}_{3}{ }^{-}$and $\mathrm{NH}_{4}^{+}$were extracted with $1 \mathrm{M} \mathrm{KCl}$ and determined by a flow injection analyzer (SAN++, Skalar, Holland). The net nitrification activity was assessed by the net increase in nitrate concentration over 21 days of incubation.

\section{Nucleic acid extraction and SIP fractionation}

DNA was extracted from $0.5 \mathrm{~g}$ of fresh soil with a FastDNA Spin Kit for Soil (MP Biomedicals, LLC., Solon, OH, USA), in accordance with the manufacturer's protocol. The DNA size and integrity were checked by electrophoresis on a $0.7 \%$ agarose gel, and the quantity and purity were estimated using a Nanodrop ND-2000 UV-Vis Spectrophotometer (NanoDrop Technologies, Wilmington, DE, USA). The extracted DNA was stored at $-20^{\circ} \mathrm{C}$ until further analysis.

Extracted DNA from ${ }^{12} \mathrm{C}-,{ }^{13} \mathrm{C}-\mathrm{CO}_{2}$ and ${ }^{12} \mathrm{C}-,{ }^{13} \mathrm{C}_{-} \mathrm{CH}_{4}$ incubations was subjected to isopycnic density gradient centrifugation to separate the ${ }^{13} \mathrm{C}$-labeled DNA from the ${ }^{12} \mathrm{C}$-labeled DNA in triplicate SIP microcosms. In brief, $\sim 3.0 \mu \mathrm{g}$ of the DNA extract was mixed with $\mathrm{CsCl}$ stock solution to achieve an initial $\mathrm{CsCl}$ buoyant density of $1.725 \mathrm{~g} \mathrm{ml}^{-1}$, by adding a small amount of gradient buffer (GB) or $\mathrm{CsCl}$ solution. The isopycnic density gradient centrifugation was performed using a 5.1-ml Quick-Seal polyallomer ultracentrifugation tube in a Vti65.2 vertical rotor (himac CP80NX, Hitachi Koki Co., Ltd. Japan) at $177,000 \mathrm{~g}$ for $44 \mathrm{~h}$ at $20^{\circ} \mathrm{C}$. CsCl density gradients displaced with sterile water from the top of the ultracentrifuge tube were fractionated into equal volumes using an NE1000 single syringe pump (New Era Pump Systems Inc., Farmingdale, NY, USA) with a precisely controlled flow rate of $0.38 \mathrm{ml} \mathrm{min}^{-1}$. A total of 15 DNA gradient fractions were obtained with about $380 \mu \mathrm{l}$ in each fraction, and $65 \mu \mathrm{l}$ of each fraction was used for measurement of the refractive index using an AR200 digital hand-held refractometer (Reichert Inc., Buffalo, NY, USA). The fractionated DNA was purified with PEG precipitation (polyethylene glycol 6000 ) and $70 \%$ ethanol, and dissolved in $30 \mu \mathrm{l}$ of sterile water.

\section{Quantitative PCR (qPCR) of the amoA and pmoA genes}

The qPCR assays targeting bacterial and archaeal amoA genes, as well as pmoA genes of total DNA extracts and DNA gradient fractions, were carried out in triplicate with LightCycler 480 (Roche Applied Science). The primers and PCR conditions used are detailed in Table S3. Each qPCR was performed in a 20- $\mu$ l reaction mixture containing $10 \mu \mathrm{l}$ SYBR Premix Ex Taq (TaKaRa, Dalian, China), $0.5 \mu \mathrm{M}$ of each primer and $1 \mu \mathrm{l}$ of DNA template $(1-10 \mathrm{ng})$ and an appropriate amount of milli-Q water to make a total volume of $20 \mu \mathrm{l}$. Melting curve analysis was performed at the end of each real-time PCR run to confirm PCR product specificity, by measuring fluorescence continuously with the temperature increasing from $50^{\circ} \mathrm{C}$ to $99^{\circ} \mathrm{C}$. High efficiencies ranging between 80.5 and $108.3 \%$ were obtained for amplification of the functional genes, with $R^{2}$ values ranging between 0.990 and 0.998 .

\section{Illumina HiSeq sequencing and phylogenetic analysis}

High-throughput sequencing of the V4 region of the 16S rRNA gene (amplified using the universal 515F-907R primer set) was used to assess the microbial community composition, including methane-oxidizers and nitrifiers. The HiSeq sequencing was carried out using the total DNA extracted from soil microcosms on day 0 and day 21 and the fractions 3-12 of the labeled $\left({ }^{13} \mathrm{CO}_{2}\right.$ and $\left.{ }^{13} \mathrm{CH}_{4}\right)$ and control $\left({ }^{12} \mathrm{CO}_{2}\right.$ and $\left.{ }^{12} \mathrm{CH}_{4}\right)$ microcosms at Day 21 (Tables S4, S5). Purified amplicons were pooled in equimolar and paired-end sequenced using an Illumina HiSeq 2500 (PE250) platform. The raw fastq files were demultiplexed, quality-filtered by Trimomatic and merged by FLASH [37] according to the following criteria: (i) the reads were truncated at any site receiving an average quality score $<20$ over a 50-bp sliding window; (ii) sequences whose overlap was longer than $10 \mathrm{bp}$ were merged according to their overlap sequence; (iii) sequences of each sample were separated according to barcodes (exactly matching) and primers (allowing two nucleotide mismatching), and reads containing ambiguous bases were removed. UPARSE was used to cluster cleaned sequences into operational taxonomic units (OTUs) at $97 \%$ similarity threshold. One representative sequence of each OTU was selected to determine taxonomic identification by RDP Classifier algorithm against the Silva (SSU128) 16S rRNA database. The 16S rRNA genes affiliated with aerobic MOB were selected based on two phyla: Proteobacteria and Verrucomicrobia. Of which, aerobic Proteobacterial MOB was divided into two major groups mainly based on phylogeny type I (Gammaproteobacteria) and type II (Alphaproteobacteria). Type I MOB harboring the family Methylococcaceae, which were further divided into type la (including genera Methylosarcina, Methylobacter, Methylomonas, Methylomicrobium, Methylosoma, Methylosphaera and Methylovulum) and type Ib (including genera Methylococcus, Methylocaldum, Methylogaea, Methylohalobius, and Methylothermus). Type II MOB include the family Methylocystaceae (including genera Methylocystis and Methylosinus) and Beijerinckiaceaea (including genera Methylocella, Methylocapsa, and Methyloferula). MmoX, a subunit of soluble methane monooxygenase, was not accounted for in the $16 \mathrm{~S}$ sequence analysis. One phylum (Thaumarchaeota) was suggested for AOA. Comparative 16S rRNA sequence analyses of cultured $A O B$ revealed that members of this physiological group are confined to two monophyletic lineages within $\beta$ - and $\gamma$-proteobacteria. The former lineage includes the genera Nitrosomonas and Nitrosospira and the latter the genera Nitrosococcus, Nitrosacidococcus and Nitrosoglobus. All reads classified as belonging to the genera Nitrococcus, Nitrospina, Nitrobacter, and Nitrospira were used for NOB phylogenetic analysis.

A representative sequence was used from each OTU of the 16S rRNA for phylogenetic analysis. Phylogenetic analysis of archaeal and bacterial amoA genes, NOB, as well as pmoA genes of total DNA and of 13C-labeled DNA, was then conducted by Molecular Evolutionary Genetic Analysis software (MEGA6.0) with 1000-fold bootstrap support. The tree topology was checked by the neighbor-joining algorithm and the minimum evolution method [38]. The entire dataset of 16S rRNA gene reads of total and fractionated DNA was deposited in NCBI's Sequence Read Archive under BioProject accession numbers PRJNA594293 and PRJNA594236, respectively.

Since it is insufficient to reveal the changes of actual taxon abundances based only on those of relative abundances by high-throughput sequencing analysis $[39,40]$, the estimated absolute abundance (EAA) of each microbial genus considering both the corresponding relative abundance and the absolute corresponding cell numbers was essential for the comprehensive analysis of the microbial community [39-41]. The EAA was calculated by multiplying the relative abundance (estimated by the sequencing) by the estimated absolute corresponding cell numbers (estimated by qPCR) [41].

\section{Statistical analysis}

One-way analysis of variance followed by Duncan's multiple range test was used to check for the significant differences between treatments for abundance of functional genes, nitrification potential, and methaneoxidizing potential using SPSS software (version 20). The independent samples $t$ test was performed with SPSS 20 (IBM) to check for the significant differences between grazed and ungrazed soils for soil physicochemical properties and $a$-diversity indices. $P<0.05$ was considered to be statistically significant. The $\alpha$-diversity indices of active methane-oxidizing bacteria and nitrifying communities were calculated using the "vegan" packages in the $R$ environment. Network analysis was performed by CoNet of cytoscape 3.6.1 based on Spearman's correlation for labeled communities of methaneoxidizers and nitrifiers in microcosms incubated at low and high levels of urea with or without methane supplementation in ungrazed and grazed soils. A co-occurrence event was validated when the Spearman's coefficient was greater than 0.65 and the $P$ value was lower than 0.01 . Nodes in the microbiome network represented individual microbial taxa (OTUs), and edges corresponded to the pairwise correlations between nodes. The network visualization was generated by Gephi 0.9.2 [42].

\section{RESULTS}

Greenhouse-gas emissions, methane, and ammonia oxidation activity

The in situ GHGs measurements revealed that total $\mathrm{N}_{2} \mathrm{O}$ emission was $0.134 \mathrm{~kg} \mathrm{ha}^{-1}$ in the ungrazed soils over the two years, and was significantly lower than that in the grazed soils $\left(0.212 \mathrm{~kg} \mathrm{ha}^{-1}\right)$ 
$(P<0.01)$ (Fig. 1). Total $\mathrm{CH}_{4}$ emission was $-3.7 \mathrm{~kg} \mathrm{ha}^{-1}$ in the ungrazed soils, and was significantly lower than that in grazed soils $\left(-2.6 \mathrm{~kg} \mathrm{ha}^{-1}\right)$.

In the incubated soils for 21 days in presence of $\mathrm{CH}_{4}$, a total of 37,51 , and $24 \mu \mathrm{mol} \mathrm{CH} \mathrm{Cg}^{-1}$ dry soil was oxidized in ungrazed soils, while 6,11 , and $3 \mu \mathrm{mol} \mathrm{CH}_{4} \mathrm{~g}^{-1}$ dry soil was oxidized in grazed soils under supplementation of 0,20 , and $100 \mu \mathrm{g} \mathrm{N} \mathrm{g}^{-1}$ of urea (Fig. 2a). Accordingly, the methane oxidation was significantly stimulated in the $\mathrm{U} 20+\mathrm{CH}_{4}$ treatments but significantly suppressed in the $\mathrm{U} 100+\mathrm{CH}_{4}$ treatments compared to $\mathrm{UO}+\mathrm{CH}_{4}$ soils during the incubation period for both ungrazed and grazed soils. The inconsistency in methane addition resulted from different methane oxidation abilities in these treatments, as we keep $1 \% \mathrm{CH}_{4}$ in the headspace of the microcosms. The inconsistency in methane addition just indicated different functional activity of methanotrophs in these treatments. The less amount of methane addition in U100-treated soils compared with that in $\mathrm{U} 0$ and U20-treated soils was ascribed to the fact that high $\mathrm{N}$ levels (U100) significantly depressed methane oxidation activity.

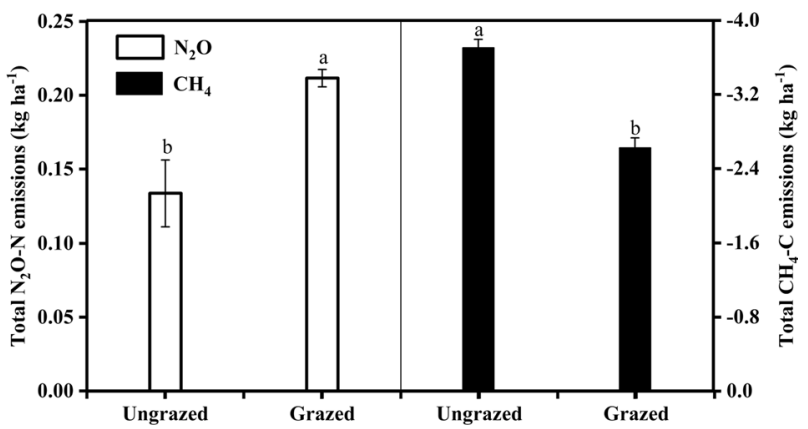

Fig. 1 Total $\mathrm{N}_{2} \mathrm{O}$ and $\mathrm{CH}_{4}$ emissions from August 2014 to October 2015 in ungrazed and grazed soils. The vertical bars indicate the standard error of the mean (S.E.M.).
In both ungrazed and grazed incubated soils, net nitrification rate was higher in soil incubated with higher concentrations of urea (Fig. 2b), with a maximum of 180 and $136 \mu \mathrm{NO}_{3}{ }^{-} \mathrm{g}^{-1}$ dry soil in U100-supplemented soils in ungrazed and grazed soils, respectively. The nitrate concentration in the soils increased during the incubation period regardless of treatments, and ammonium decreased conversely over time with a sharper decrease during the first 7-days of the incubation (Fig. S2). Methane supplementation did not impact nitrification rate, apart in U20-supplemented ungrazed soils, for which nitrification was reduced from 89 to $41 \mu^{-1}$ following methane addition (Fig. 2b).

\section{Abundance of methylotrophic and nitrifying communities}

The abundance of pmoA-related organisms increased during the incubation under low urea supplementation (U20) in both ungrazed and grazed soils, but decreased dramatically for the high urea supplementation treatment (U100) compared to the control treatment (Fig. 3a; Table S6). A similar trend was observed for the relative abundance of methylotrophs estimated by $16 \mathrm{~S}$ rRNA gene sequencing in microcosms incubated for 21 days (Fig. 3b; Table S6). The relative abundance of $16 \mathrm{~S}$ rRNA genes affiliated with methane-oxidizing bacteria in both ungrazed and grazed soils was significantly stimulated by the low rate of urea addition $\left(20 \mathrm{\mu g} \mathrm{N} \mathrm{g}^{-1}\right)$, and decreased following the addition of $100 \mu \mathrm{g}$ urea- $\mathrm{N} \mathrm{g}^{-1}$ compared to those without urea addition.

The abundance of bacterial $a m o A$ gene increased significantly over time in both ungrazed and grazed soils supplemented with high urea (Fig. 3c; Table S7). After incubation, the bacterial amoA gene abundance was significantly higher in U100- than in U20treated soils. Methane addition did not affect the bacterial amoA gene abundance. The dynamic changes of the relative abundance of $16 \mathrm{~S}$ rRNA genes affiliated with AOB were similar to the variations of bacterial $a m o A$ genes copy numbers under urea and methane treatments in both ungrazed and grazed soils (Fig. 3e; Table S7). By comparison, irrespective of methane addition, the abundance as

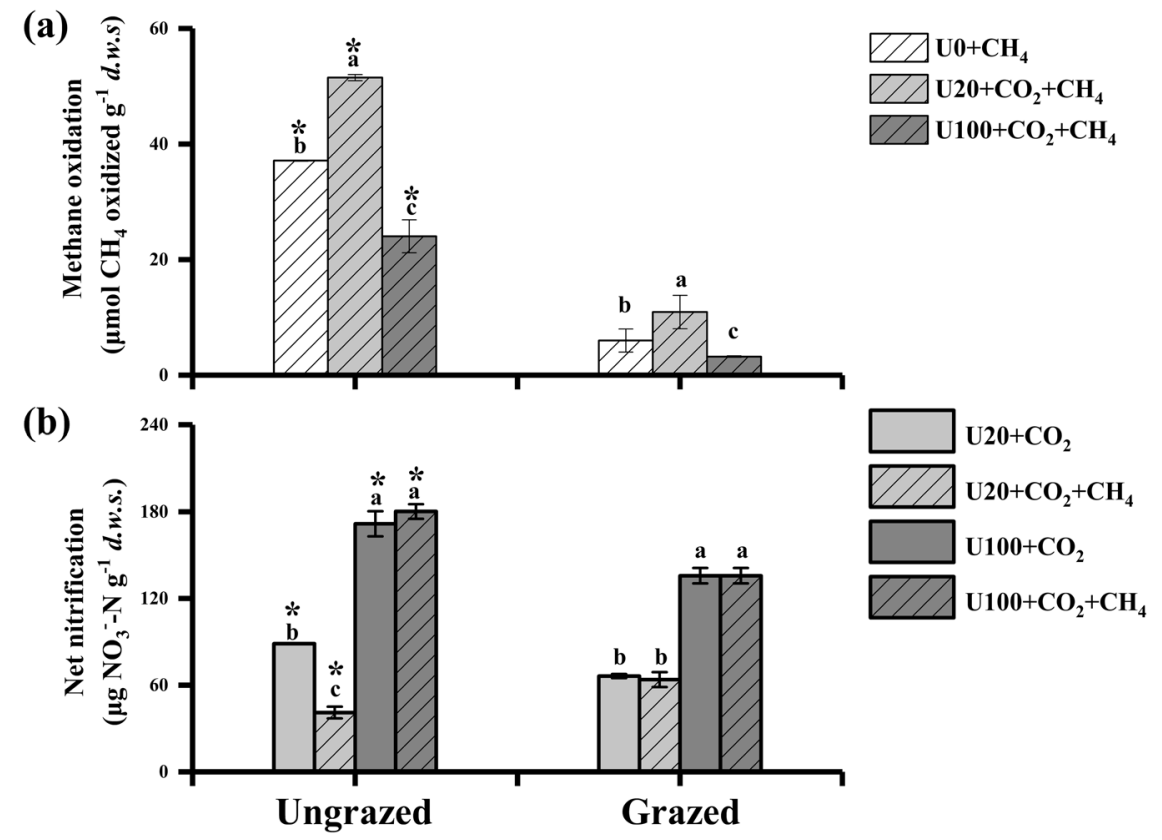

Fig. 2 Interactions between methane and ammonia oxidation in grassland soils. Methane oxidation (a) and nitrification (b) after incubation for 21 days in the ungrazed and grazed soils at weekly urea addition of 0 (U0), 20 (U20), and $100 \mu \mathrm{g} \mathrm{N} \mathrm{g}^{-1}$ (U100) in presence or absence of methane addition $\left(1 \% \mathrm{CH}_{4}\right)$. Methane oxidation was calculated by methane consumption in the microcosms in presence or absence of urea addition, while nitrification was assessed by nitrate production. The error bars represent standard errors of three replicates for the $\mathrm{U} 0+\mathrm{CH}_{4}$ treatments, and six replicates for the U20 and U100 treatments $\left({ }^{12} \mathrm{C}+{ }^{13} \mathrm{C}\right.$-labeled treatments). Different lower-case letters indicate significant differences among different treatments. Asterisks indicate significant difference between ungrazing and grazing under the same treatment. $d$. W.s. refers to dry weight of soil. 
(a)

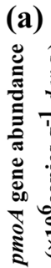

(a)

(b)
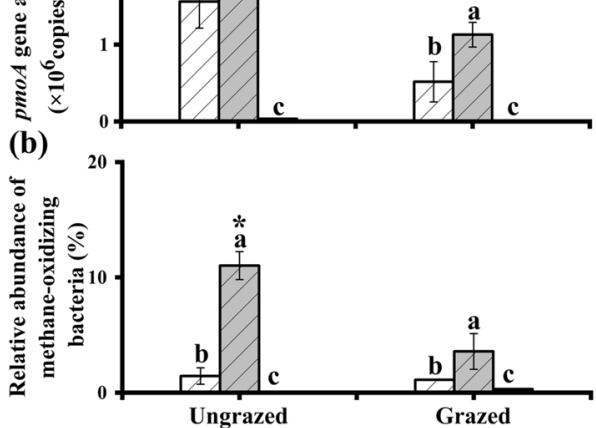
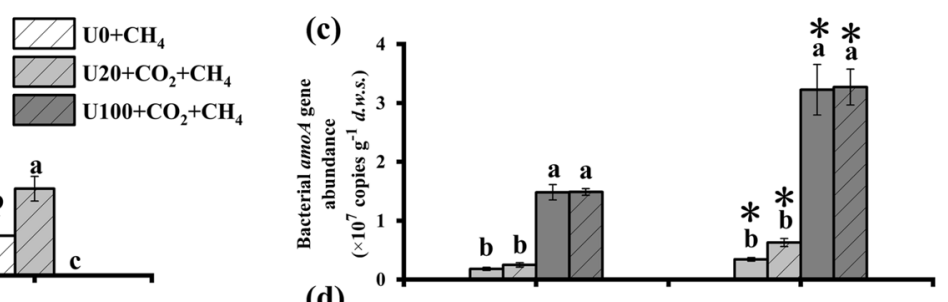

(d)
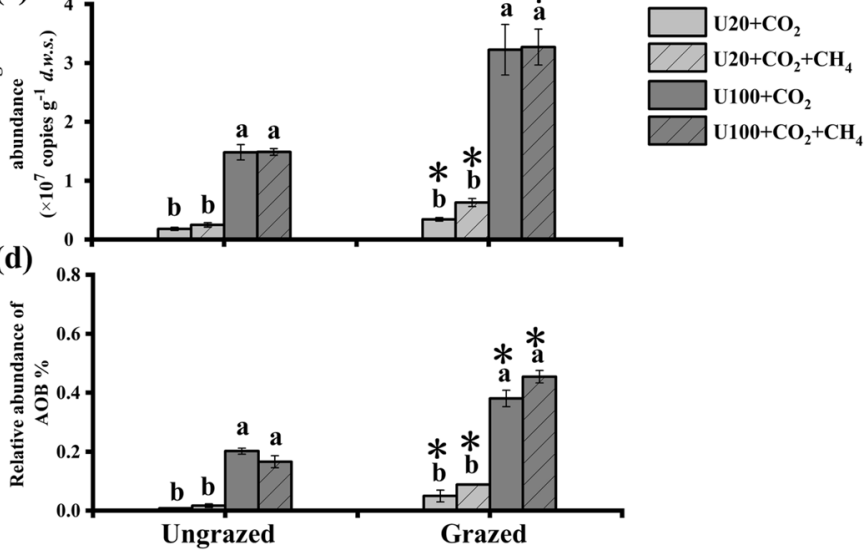

Fig. 3 Changes of abundance of methylotrophs and AOB amoA genes in soil microcosms over a 21-days incubation in ungrazed and grazed soils following weekly urea addition of 0 (U0), 20 (U20), and $100 \mu \mathrm{g} \mathrm{N} \mathrm{g}^{-1}$ (U100) in presence or absence of methane addition (1\% $\mathbf{C H}_{\mathbf{4}}$ ). The pmoA gene abundance (a), the relative abundance of targeted 16S rRNA genes affiliating with methane-oxidizing bacteria (b), the amoA gene copy numbers in total DNA (c), relative frequencies of targeted 16S rRNA genes affiliating with ammonia-oxidizing bacteria in total reads (\%) (d) in the ungrazed and grazed soils after 21-day incubation were represented. The error bars represent standard errors of three replicates for the $\mathrm{UO}+\mathrm{CH}_{4}$ treatments, and 6 replicates for the $\mathrm{U} 20$ and $\mathrm{U} 100$ treatments $\left({ }^{12} \mathrm{C}+{ }^{13} \mathrm{C}\right.$-labeled treatments) (a-c). The error bars represent standard errors of six replicates for the U20 and U100 treatments $\left({ }^{12} \mathrm{C}+{ }^{13} \mathrm{C}\right.$-labeled treatments) (d, e). Different lower-case letters indicate significant differences among different treatments. Asterisks indicate significant difference between ungrazing and grazing under the same urea treatment. d.w.s. refers to dry weight of soil.

well as the relative abundance of Thaumarchaeota (including all known AOA) decreased significantly during the incubation period with urea addition in both ungrazed and grazed soils (Fig. S3).

In ungrazed soils, the relative abundance of targeted $16 \mathrm{~S}$ rRNA genes affiliated with NOB increased over time in U20, U100, and $\mathrm{U} 100+\mathrm{CH}_{4}$ microcosms, but remained constant in $\mathrm{U} 20+\mathrm{CH}_{4}$ microcosms (Fig. S4a). On the contrary, in grazed soils, the relative abundance of NOB only increased in U100-treated microcosms (Fig. S4b).

Active methane-oxidizing bacteria and nitrifying communities Isopycnic gradient centrifugation was conducted on the total DNA from each treatment to detect which putative autotrophic methane- and ammonia- oxidizers were incorporating ${ }^{13} \mathrm{C}_{-} \mathrm{CH}_{4}$ or ${ }^{13} \mathrm{C}_{-} \mathrm{CO}_{2}$ during the 21-day incubation (Fig. 4). The buoyant density in the 15 fractions ranged from 1.676 to $1.786 \mathrm{~g} \mathrm{ml}^{-1}$ from the top to the bottom of the ultracentrifugation tube. The abundances of $p m o A$ and $a m o A$ genes in the 15 fractions were determined by specific qPCR assays (Figs. 4 and S5).

In ungrazed soils, the copy numbers of $p m o A$ genes in all ${ }^{13} \mathrm{C}$-spiked microcosms peaked in heavy fractions $(1.738-1.778 \mathrm{~g}$ $\left.\mathrm{ml}^{-1}\right)$, while those in the presence of ${ }^{12} \mathrm{CH}_{4}$ were detected in fractions with lower buoyant densities (between 1.680 and 1.738 $\mathrm{g} \mathrm{ml}^{-1}$ ) (Fig. 4a-C). In grazed soils, a shift of DNA buoyant density also occurred towards the heavy fractions $\left(1.732-1.770 \mathrm{~g} \mathrm{ml}^{-1}\right)$ in microcosms with ${ }^{13} \mathrm{CH}_{4}$ under $\mathrm{UO}$ and $\mathrm{U} 20$ treatments, but to a lesser extent than in the ungrazed soils. In addition, the distributions of $p m o A$ gene abundance in microcosms with ${ }^{12} \mathrm{CH}_{4}$ and microcosms under $\mathrm{U} 100+{ }^{13} \mathrm{CH}_{4}$ treatments were mainly in lighter fractions $\left(1.698-1.732 \mathrm{~g} \mathrm{ml}^{-1}\right)$ with no peak reported in the heavy fractions (Fig. $4 \mathrm{f}-\mathrm{h}$ ). Sequencing of the V3-V4 region of the $16 \mathrm{~S}$ rRNA gene generated 1,124,000 and $1,088,000$ high-quality reads in ungrazed and grazed soils, respectively (Table S4). The labeling of MOB was further supported by distribution of relative abundance of methanotrophs across the whole buoyant density (Fig. S6).

The ${ }^{13} \mathrm{C}$-labeling of the AOB populations was stronger in the U100 than U20 treatments in both ungrazed and grazed soils irrespectively of methane addition treatment (Fig. $4 \mathrm{~d}$, e and i, j). For the ${ }^{12} \mathrm{CO}_{2}$ controls (U2O $+{ }^{12} \mathrm{CO}_{2}+{ }^{12} \mathrm{CH}_{4}$ and $\mathrm{U} 100+{ }^{12} \mathrm{CO}_{2}+{ }^{12} \mathrm{CH}_{4}$ ), the $\mathrm{AOB}$ amoA gene relative abundance was distributed in the light fractions $\left(1.705-1.738 \mathrm{~g} \mathrm{ml}^{-1}\right)$. A small but detectable shift of DNA buoyant density was detected in $\mathrm{U} 20+{ }^{13} \mathrm{CO}_{2}$ microcosms with the relative abundance of $A O B$ peaking in the heavy fractions $\left(1.732-1.742 \mathrm{~g} \mathrm{ml}^{-1}\right.$ ) (Fig. 4d and i). A major shift into the heavier fractions was detected for bacterial amoA genes in $\mathrm{U} 100+{ }^{13} \mathrm{CO}_{2}$ microcosms, with a buoyant density of $1.750 \mathrm{~g} \mathrm{ml}^{-1}$ (Fig. 4e and j). In contrast, no significant difference of migration between the ${ }^{12} \mathrm{CO}_{2}$ and ${ }^{13} \mathrm{CO}_{2}$ treatments was observed for the archaeal amoA gene (Fig. S5). The relative frequency of the 16S rRNA gene sequences affiliated with ammonia oxidizers across the whole buoyant density gradient of DNA fractions suggested the similar labeling trend to that of $a m o A$ gene abundance in the "heavy" DNA fractions (Fig. S7). Combined with the results that AOA amoA genes abundances decreased during incubation (Fig. S3), suggested that AOA was not important for ammonia oxidation in the grassland soil tested. Therefore, the possible bias against Thaumarchaeota due to primers used in the present study exerted little effect on the results.

In both ungrazed and grazed soils, a higher proportion of $16 \mathrm{~S}$ rRNA genes affiliating to NOB were labeled in the ${ }^{13} \mathrm{CO}_{2}$ than in the ${ }^{12} \mathrm{CO}_{2}$ treatments, with more labeling happening in the absence of ${ }^{13} \mathrm{CH}_{4}$, apart from the grazed microcosms with highest urea addition treatment (Fig. S8).

\section{Diversity of active methane-oxidizing bacteria and nitrifying communities}

There were obvious dissimilarities $(P<0.05)$ in diversity of active methane-oxidizing bacteria and nitrifying communities for the Shannon's and Simpson's indexes, respectively (Fig. 5). The Shannon's and Simpson's indexes of active MOB and AOB were significantly higher in ungrazed soils than those in grazed soils, while the variation of those of NOB was not significant between ungrazed and grazed soils. Grazing, therefore, significantly decreased the community diversity of active ammonia oxidizers and methanotrophs.

\section{Phylogenetic analysis of active MOB and AOB}

The taxonomic analysis focused on the organisms present in the "heavy fractions" in the ${ }^{13} \mathrm{CO}_{2} /{ }^{13} \mathrm{CH}_{4}$ microcosms, as these $\mathrm{AOB}$, $\mathrm{NOB}$ and $\mathrm{MOB}$ were actively growing (Figs. 4; S5-S8).

The majority of ${ }^{13} \mathrm{C}$-labeled $\mathrm{MOB}$ in ungrazed soils mainly belonged to Methylobacter, with some Methylocaldum and USCa, and AOB mainly grouped with Nitrosospira, with some 
Relative abundance of $p m o A$ gene in $\mathrm{CsCl}$ gradient
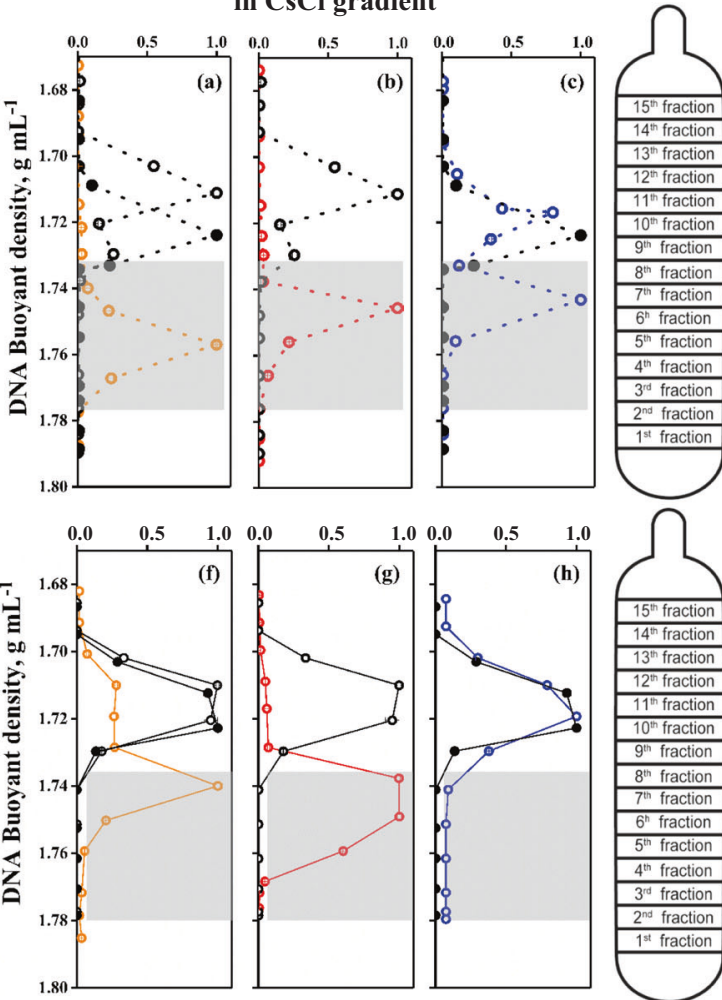

Relative abundance of bacterial $a m o A$ gene in $\mathrm{CsCl}$ gradient
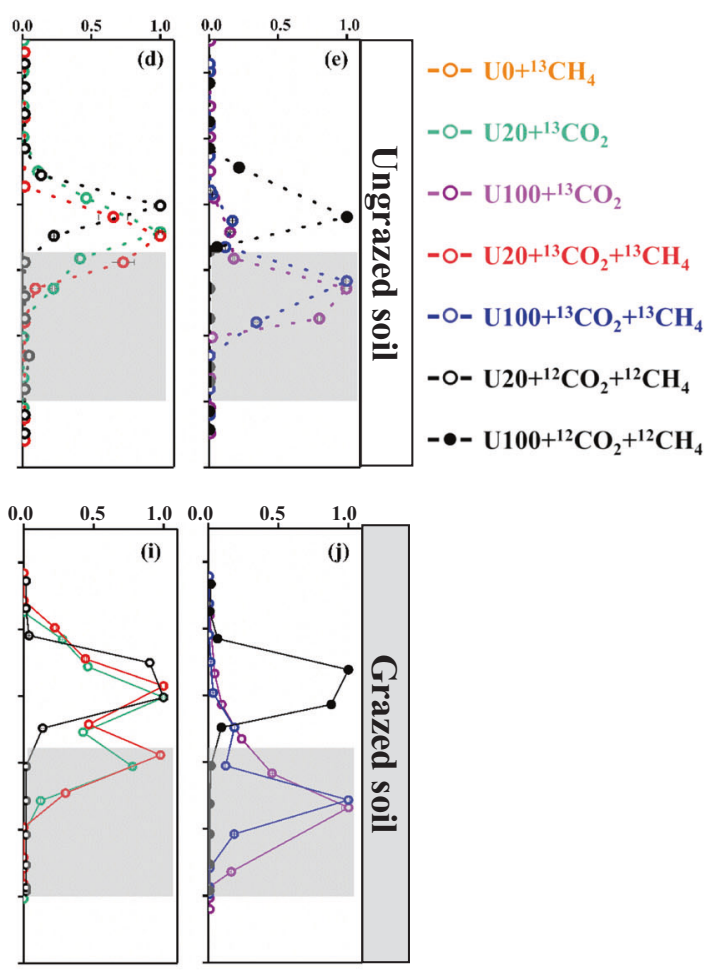

Fig. 4 Distribution of pmoA and amoA gene copy numbers in fractionated DNA across the buoyant density. Quantitative distribution of pmoA genes (a-c, $\mathbf{f}-\mathbf{h})$, and bacterial $a m o A$ genes $(\mathbf{d}, \mathbf{e}, \mathbf{i}, \mathbf{j})$ across the entire buoyant density gradient of the fractionated DNA from the ungrazed (a-e) and grazed (f-j) soils at weekly urea addition of 0 (U0), 20 (U20), and $100 \mu \mathrm{g} \mathrm{N} \mathrm{g}^{-1}$ (U100), in presence or absence of methane addition $\left(1 \% \mathrm{CH}_{4}\right)$ after incubation for 21 days. The normalized data are shown as the ratio of the gene copy number in each fraction to the maximum quantities in each treatment. The dotted and plain lines represent samples in ungrazed and grazed soils, respectively.

Nitrosomonas, and Nitrosococcus (Figs. 6a, c and S9). By contrast, the ${ }^{13} \mathrm{C}$-labeled $\mathrm{MOB}$ and $\mathrm{AOB}$ in grazed soils were almost exclusively affiliated with Methylobacter and Nitrosospira, respectively (Figs. 6b, d and S9). In ungrazed soils, over $98 \%$ of active $\mathrm{MOB}$ sequences were derived from Methylobacter species in low and high urea amended soils, while $59.9 \%$ of active MOB were affiliated with Methylobacter in no urea treated soils (Fig. 6a).

The active AOB community grouped with Nitrosospira was significantly decreased from $67.0 \%$ and $71.1 \%$ in low and high urea treated soils without methane addition, respectively, to $65.5 \%$ and $62.6 \%$ in microcosms with methane addition (Fig. $6 \mathrm{c}$ ). In stark contrast, the active AOB classified into Nitrosomonas was significantly increased by methane addition in both low and high $\mathrm{N}$ soils. Irrespective of methane addition, the active AOB community classifying as Nitrosococcus was suppressed by high relative to low urea addition.

\section{Absolute abundance of different active microbial genera affiliated with MOB and AOB}

The estimated absolute abundances (EAA) of the major active genera affiliated with active $M O B$ and $A O B$ were performed based on the combined analysis of specific qPCR and Illumina HiSeq sequencing analysis (Fig. 7). The EEA results showed that Methylobacter lineage of $\mathrm{MOB}$ was the dominant active $\mathrm{MOB}$ in the grassland ecosystems (Fig. 7a, b). The Methylocaldum and USCa lineages of $\mathrm{MOB}$ were exclusively observed in ungrazed soils without urea addition (Fig. 7a). In both ungrazed soils and in grazed soils, the addition of U20 significantly increased while U100 decreased the absolute abundance of active Methylobacter lineage of $\mathrm{MOB}$ (Fig. $7 \mathrm{a}, \mathrm{b}$ ). The active bacterial $a m o A$ genes fell within Nitrosospira, Nitrosomonas, and Nitrosococcus, with Nitrosospira accounting for the largest percentage among labeled microcosms (Fig. 7c, d). In ungrazed soils, the absolute abundance of the three lineages of AOB was higher in U100 than U20 microcosms (Fig. 7c). In grazed soils, the absolute abundance of Nitrosospira was 3.25-fold higher in U100 compared to U20 (Fig. 7d).

\section{Network description}

Network analysis based on co-occurring patterns of $A O B, N O B$, and MOB in "heavy fractions" in all microcosms was implemented to investigate potential relationships between the three functional guilds in ungrazed and grazed soils (Fig. 8). The resulting topological properties commonly used in network analysis in terms of the numbers of nodes and edges, average connectivity, and average clustering coefficient were detailed in Table S8. Positive and strong correlations $(P<0.05)$ were observed between active AOB and NOB phylotypes, while negative correlations $(P<$ 0.05 ) were discerned between active $M O B$ and the two abovementioned nitrifiers in both ungrazed and grazed soils. In ungrazed soils, OTU 2, which fell within the Methylobacter and was the most abundant phylotype of active MOB (more than $80 \%$ of active $\mathrm{MOB}$ sequences), exhibited strong negative correlations with OTU 9, OTU 466, and OTU 703, which were affiliated with Nitrosospira, Nitrosococcus, and Nitrosococcus, respectively (Fig. 8a). Furthermore, in grazed soils, a strong and negative relationship was detected between Methylobacter and Nitrosospira (Fig. 8b)

\section{DISCUSSION}

Grazing reduced $\mathrm{CH}_{4}$ uptake and increased $\mathrm{N}_{2} \mathrm{O}$ emissions

Grazing, associated with trampling, excreta patches and grazing grass, greatly alters plant growth, soil properties, and nutrient 

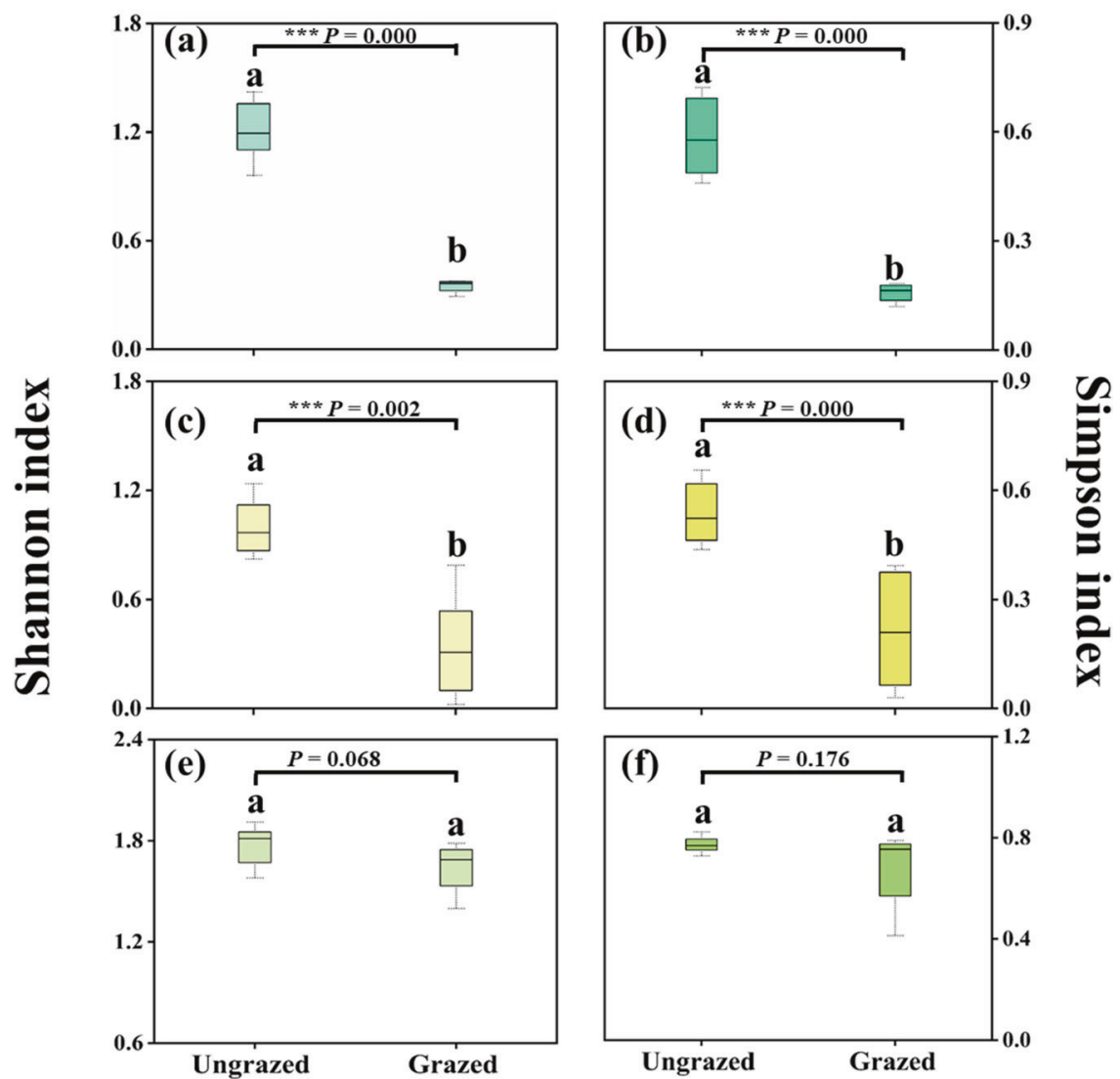

Fig. 5 Alpha-diversity indices of active methanotrophs and nitrifiers in grassland soils. Alpha-diversity measurements of Shannon index (a, $\mathbf{c}, \mathbf{e})$ and Simpson index $(\mathbf{b}, \mathbf{d}, \mathbf{f})$ of active $\mathrm{MOB}(\mathbf{a}, \mathbf{b}), \mathrm{AOB}(\mathbf{c}, \mathbf{d})$ and $\mathrm{NOB}(\mathbf{e}, \mathbf{f})$ in ungrazed and grazed soils. Different letters indicate significant differences $(P<0.05)$ based on the analysis of variance.

transformations, especially affecting soil C/N cycling [31, 43, 44]. A large number of studies investigating the effects of grazing on GHGs emissions have proposed that grazing caused a significant decline in soil $\mathrm{CH}_{4}$ uptake $[21,43,45]$. It was reported that soil compaction [46-48] and drought or waterlogging stress [49] decreased methane oxidation and increased methane production. The inhibition effects of grazing on $\mathrm{CH}_{4}$ consumption in the present study could thus be mediated by soil bulk density and moisture, which were appreciably increased and decreased under grazing, respectively, as evidenced by the strong relationships between $\mathrm{CH}_{4}$ uptake and bulk density $(r=-0.962)$ and soil moisture $(r=0.966)$ (Table 1$)$. Intriguingly, the effect of grazing on $\mathrm{N}_{2} \mathrm{O}$ emissions remains controversial. The stimulating effects of grazing on $\mathrm{N}_{2} \mathrm{O}$ emissions in the present study were supported by previous studies [50-52], while contrasting results were also reported [45]. However, the $\mathrm{N}_{2} \mathrm{O}$ emissions observed under the grazing treatment are highly dependent on the season, with most of the annual $\mathrm{N}_{2} \mathrm{O}$ emissions being reported from semi-arid grasslands experiencing soil freeze-thaw cycles during the spring season, while grazing decreases $\mathrm{N}_{2} \mathrm{O}$ emissions during the spring thaw period $[45,53]$, and our present measurements were taken during the grass growing season from May to October annually within 14-months. Therefore, GHGs emissions from grazed grassland soils are a result of multiple factors, including the soil properties, climate conditions, and anthropogenetic activities. The quantitative environmental impact of grazing on the global nitrogen cycle and on greenhouse gas emission needs to be fully considered and quantified to provide comprehensive recommendations for future grassland management.

\section{Communities and activity of methanotrophs and nitrifiers}

The significant higher Shannon's and Simpson's indexes in ungrazed soils revealed that diversity of active $M O B$ and $A O B$ in ungrazed soils were higher than those in grazed soils. We may therefore conclude that grazing decreases the community diversity of active nitrifiers and methanotrophs in grassland soils. This could be the direct reasons why grazing suppressed $\mathrm{CH}_{4}$ oxidation and nitrification activity (Fig. 2).

The strong positive correlation $(r=0.841, P<0.05)$ between $A O B$ amo $A$ gene abundance and nitrification activity, together with the results of DNA-SIP, indicate that $A O B$ rather than $A O A$ dominated microbial ammonia oxidation in the grassland soils. The predominant role of $A O B$ in ammonia oxidation is consistent with previous studies showing that $A O B$ generally dominates ammonia oxidation in $\mathrm{N}$ fertilized neutral $\mathrm{pH}$ agricultural soils [14, 54-57], while AOA may dominate ammonia oxidation in acidic agricultural soils [58,59] or in unfertilized grassland soils [60]. Surprisingly, albeit the low nitrification activity, grazing appreciably increased $\mathrm{N}_{2} \mathrm{O}$ emissions as well as $\mathrm{AOB}$ amoA gene copy numbers and absolute abundance of active $A O B$ affiliated with Nitrosospira (Figs. 1, 2, 6, 7). Apart from the soil conditions caused by grazing favored for $\mathrm{N}_{2} \mathrm{O}$ emissions, the significant increase of active $\mathrm{AOB}$ affiliated with Nitrosospira could also partially explain the distinct increase of $\mathrm{N}_{2} \mathrm{O}$ emission in grazed soils, as Nitrosospira were considered as the main contributors to the $\mathrm{N}_{2} \mathrm{O}$ emissions [61]. The active AOB in grazed soils were all affiliated with Nitrosospira while those in ungrazed soils were grouped into Nitrosospira and Nitrosomonas (Fig. 6). Nitrosospira strains were previously shown to outcompete Nitrosomonas in microcosms [62] while Nitrosomonas has a greater nitrification 
(a)

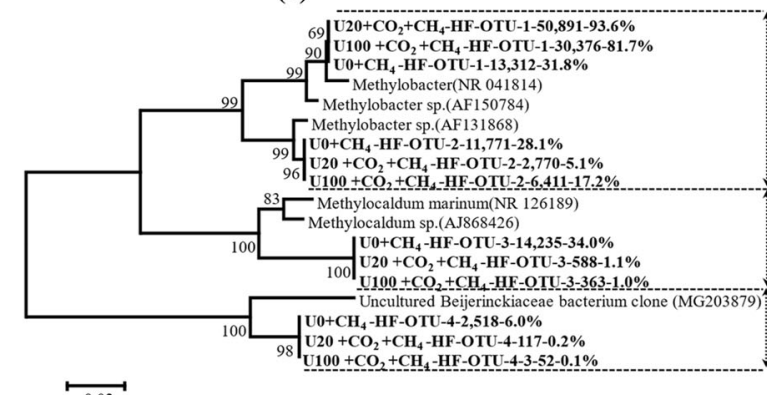

(c)

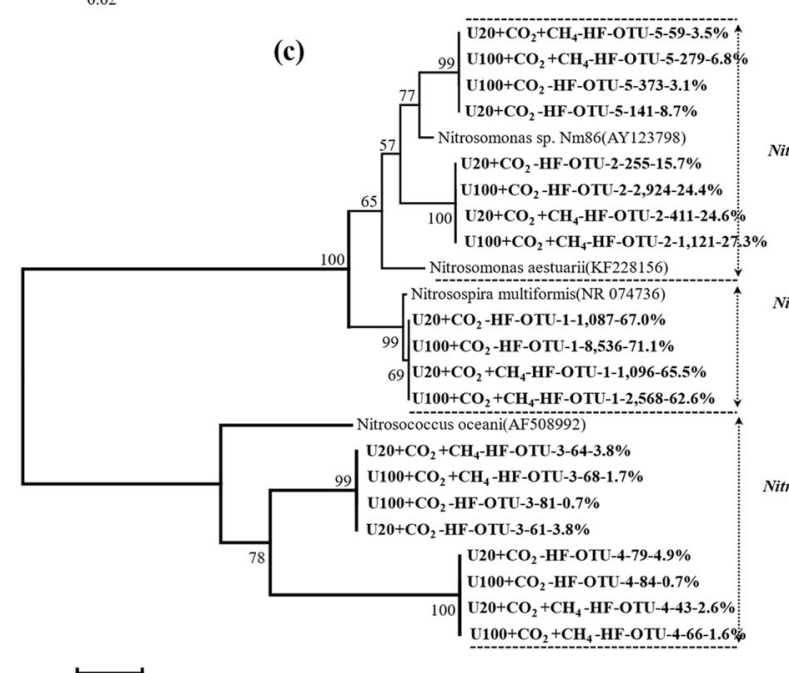

(b)

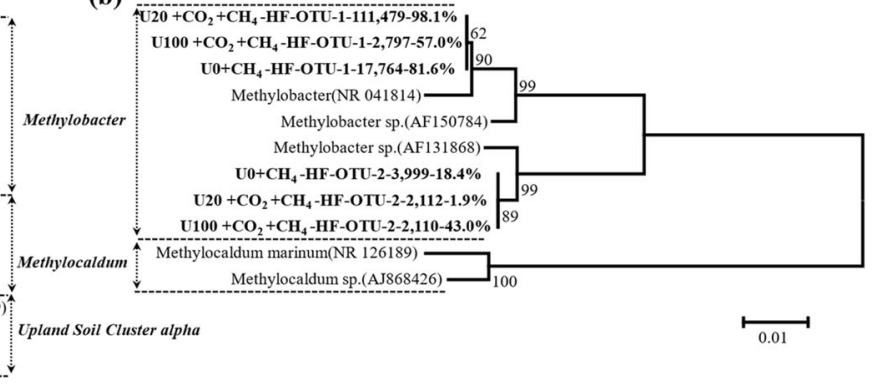

(d)

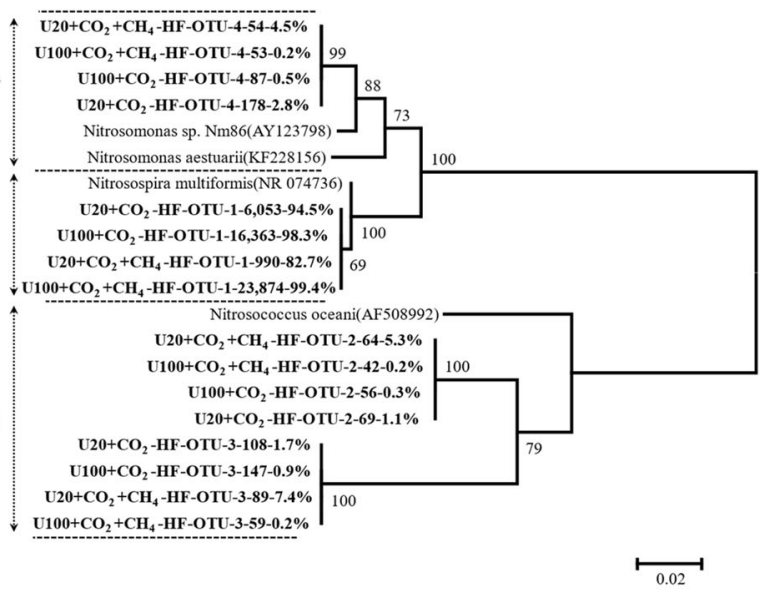

Fig. 6 Phylogenetic tree of the ${ }^{13} \mathrm{C}$-labeled $16 \mathrm{~S}$ rRNA genes affiliated with MOB and AOB from the labeled microcosms after incubation for 21 days. Phylogenetic analysis of the 16S rRNA genes affiliated with MOB (a, b) and AOB (c, d) in ${ }^{13}$ C-labeled DNA. The designation "HF" indicates the ${ }^{13} \mathrm{C}$-DNA in the active fraction after the ultracentrifugation of the total DNA extract from the labeled microcosms. The designation "U0 $+\mathrm{CH}_{4}$-HF-OTU-1-13,312-31.8\%" indicates that OTU-1 contains 13,312 reads with > 97\% sequence similarity, accounting for $31.8 \%$ of the total MOB $16 \mathrm{~S}$ rRNA gene reads in the ${ }^{13} \mathrm{C}$-DNA from the $\mathrm{CH}_{4}$-treated soil microcosms. The scale bars represent $1 \%$ nucleic acid sequences divergence for the 16SrRNA genes in ungrazed (a) and grazed (b) soils, respectively. The designation "HF" indicates the ${ }^{13} \mathrm{C}$-DNA in the active fraction after the ultracentrifugation of the total DNA extract from the labeled microcosms. The designation "U20 $+\mathrm{CO}_{2}$-HF-OTU-1-1,087-67.0\%" indicates that OTU-1 contains 1087 reads with > 97\% sequence similarity, accounting for $67.0 \%$ of the total bacterial AOB $16 \mathrm{~S}$ rRNA gene reads in the ${ }^{13} \mathrm{C}$-DNA from the U20-treated soil microcosms. The designation "U20 + $\mathrm{CO}_{2}+\mathrm{CH}_{4}$-HF-OTU-1-1,096-65.5\%" indicates that OTU-1 contains 1096 reads with $>97 \%$ sequence similarity, accounting for $65.5 \%$ of the total bacterial AOB $16 \mathrm{~S}$ rRNA gene reads in the ${ }^{13} \mathrm{C}$-DNA from the $\mathrm{U} 20+\mathrm{CO}_{2}+\mathrm{CH}_{4}$-treated soil microcosms. The scale bars represent $2 \%$ nucleic acid sequences divergence for the 16SrRNA genes in ungrazed (c) and grazed (d) soils, respectively.

activity potential than Nitrosospira [63]. These findings might explain the unexpected increase of active $A O B$ abundance with low nitrification activity in grazed soils. A field in situ experiment revealed that excreta depositions considerably stimulated $\mathrm{N}_{2} \mathrm{O}$ emissions from nitrifier denitrification dominated by $A O B$ in grassland ecosystems $[44,64]$. Combined with the results that $\mathrm{AOB}$ dominated nitrification, we proposed that the high $\mathrm{N}_{2} \mathrm{O}$ emissions in the grazed soils resulted from nitrifier denitrification possessed by Nitrosospira AOB in the present study. Although we failed to explore the activity of comammox in the grassland soils, comammox were found to lack NOR homologs and cannot produce $\mathrm{N}_{2} \mathrm{O}$ via nitrifier denitrification [65]. Meanwhile, comammox yielded $\mathrm{N}_{2} \mathrm{O}$ at levels that are comparable to AOA but much lower than $A O B$ via nitrification [66]. Therefore, these results suggest that grazing tends to convert major $\mathrm{N}_{2} \mathrm{O}$-generating processes from nitrification to nitrifier denitrification, which was dominated by Nitrosospira lineage of $A O B$ in grassland soils. Nevertheless, more studies are needed to quantify the contribution of nitrification and nitrifier denitrification to $\mathrm{N}_{2} \mathrm{O}$ emissions in grazing grassland in future.

\section{Nitrogen-triggered relationships between $\mathrm{CH}_{4}$ oxidation and nitrification}

The methane oxidation was increased and decreased under low and high urea addition, respectively, compared to the non-urea microcosm in both ungrazed and grazed soils (Fig. 2a). Similarly, both the $p m o A$ copy numbers and the relative frequency of targeted 16S rRNA affiliated with methanotrophs were stimulated by the low rate of urea addition but suppressed by the high urea addition (Fig. 3). It has been reported that the response of the methanotrophs to different $\mathrm{N}$ levels is inconsistent, which is traditionally ascribed to the inherent characteristics of the methanotroph composition or the $\mathrm{N}$ load-tested [67]. In fact, the mineral $\mathrm{N}$ is essential for methanotrophs to form biomass [68]. That is why urea addition is usually observed to stimulate methane oxidation and MOB growth in soil [14-16]. The grassland soils in our present study had low fertility with low mineral $\mathrm{N}$ levels (Table 1), so the addition of $20 \mu \mathrm{g}$ urea- $\mathrm{N} \mathrm{g}^{-1}$ increased the abundance of $\mathrm{MOB}$ communities (Fig. 3), resulting in the higher methane-oxidizing activity than in the absence of urea (Fig. 2a). By contrast, the application of $100 \mu \mathrm{g}$ urea- $\mathrm{Ng}^{-1}$ reduced both 

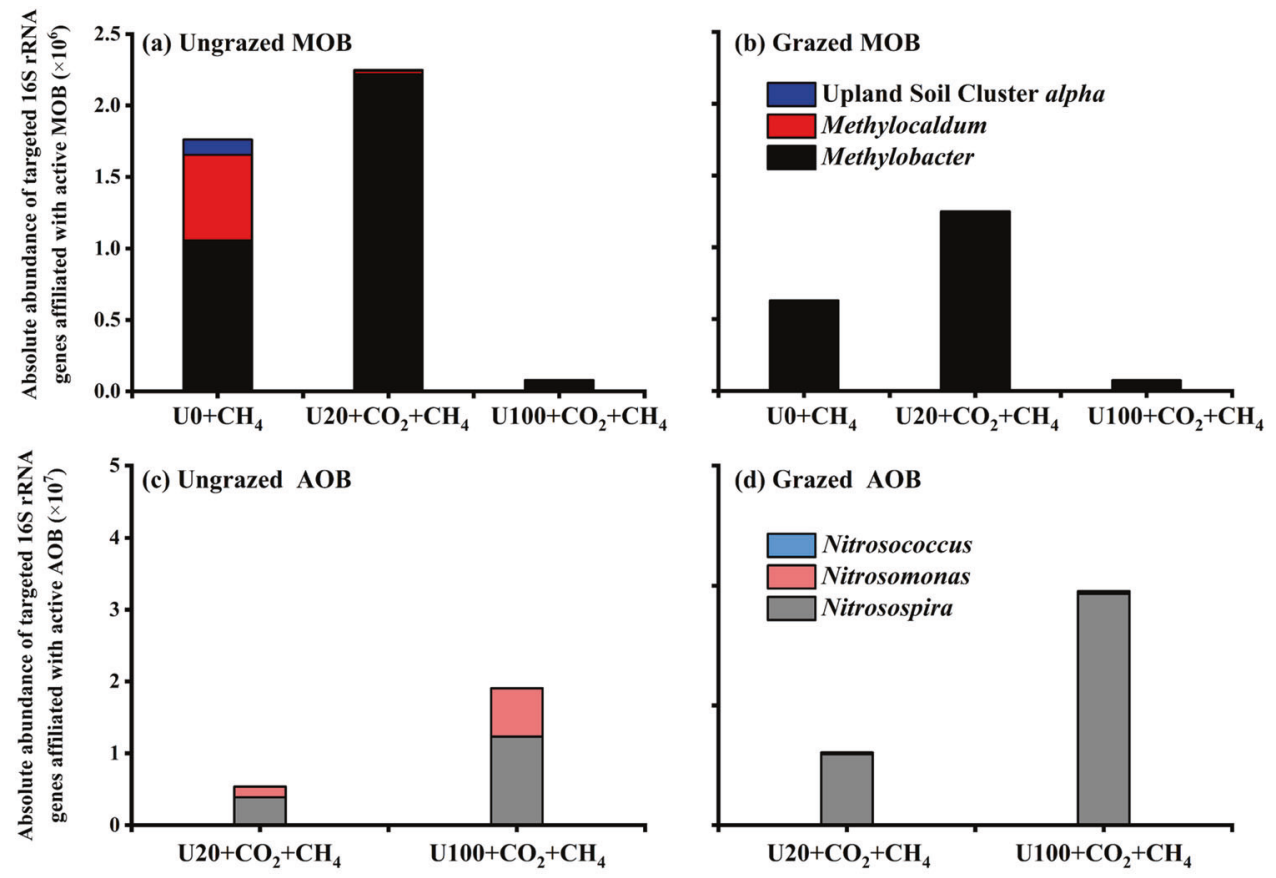

Treatments

Treatments

Fig. 7 The estimate absolute abundance (EEA) of active MOB and AOB in grassland soils. Comparison of the EAA of the major active genera affiliated with $\mathrm{MOB}(\mathbf{a}, \mathbf{b})$ and $\mathrm{AOB}(\mathbf{c}, \mathbf{d})$ in the ungrazed $(\mathbf{a}, \mathbf{c})$ and grazed $(\mathbf{b}, \mathbf{d})$ soils after 21-day incubation with weekly urea addition of 0 (U0), 20 (U20), and $100 \mu \mathrm{g} \mathrm{N} \mathrm{g}^{-1}$ (U100), and $1 \%$ methane $\left(\mathrm{CH}_{4}\right)$.
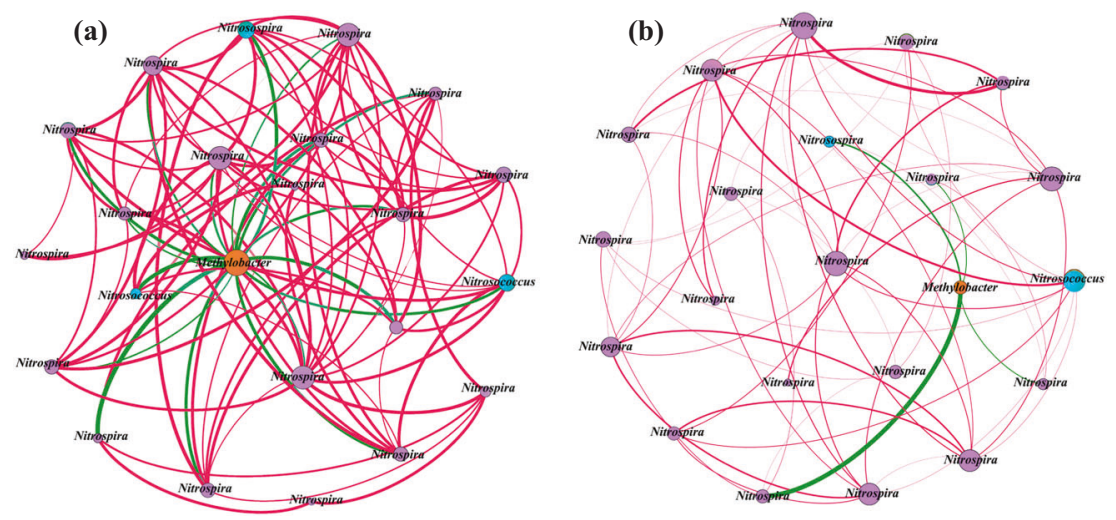

label. Мов

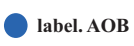

label. NOB

- pos. corr.

- neg. corr.

Fig. 8 Network analysis of co-occurring active phylotypes of methanotrophs and nitrifiers in grassland soils. The co-occurring network of active MOB, AOB and NOB after 21-day incubation in the ungrazed (a) and grazed (b) soils at weekly urea addition of 20 (low) and $100 \mu \mathrm{g} \mathrm{N} \mathrm{g}{ }^{-1}$ (high) with and without $1 \%$ methane addition. Nodes represent the labeled OTUs of each of the three functional guilds, which were actively labeled with ${ }^{13} \mathrm{C}$. Isolated nodes were removed. Connecting lines (edges) correspond to significantly $(P<0.05)$ positive (red) or negative (green) correlations between nodes, where thicker lines represent stronger correlations. Labeled MOB: OTU 2 (Methylobacter); Labeled AOB: OTU 9 (Nitrosospira), OTU 466 (Nitrosococcus), OTU 703 (Nitrosococcus); Labeled NOB: OUT 5, OUT 12, OTU 55, OTU 75, OTU 126, OTU 133, OTU 191, OTU 622, OTU 816, OTU 919, OTU 2489, OTU 7401 (Nitrospira). The size of each node is proportional to the number of connections (i.e., degree), and the thickness of each connection between two nodes (i.e., edge) is proportional to the value of correlation coefficients. Green edges indicate positive relationships between two individual nodes, while red edges indicate negative relationships.

Table 1. Physicochemical properties of the grassland soils used in this study.

\begin{tabular}{|c|c|c|c|c|c|c|c|c|c|c|}
\hline Soil & pH & $\begin{array}{l}\text { Soil } \\
\text { moisture (\%) }\end{array}$ & $\begin{array}{l}\text { Bulk density } \\
\left(\mathrm{g} \mathrm{cm}^{-3}\right)\end{array}$ & $\begin{array}{l}\text { Soil organic } \\
\text { matter }\left(\mathrm{g} \mathrm{kg}^{-1}\right)\end{array}$ & $\begin{array}{l}\text { Total } \mathbf{N} \\
\left(g^{-1} \mathbf{~ g ~}^{-1}\right)\end{array}$ & $\begin{array}{l}\text { Total C } \\
\left(\mathrm{g} \mathrm{kg}^{-1}\right)\end{array}$ & $\begin{array}{l}\text { Olsen P } \\
\left(\mathbf{m g ~ k g}^{-1}\right)\end{array}$ & $\begin{array}{l}\text { Available K } \\
\left(\mathrm{mg} \mathrm{kg}^{-1}\right)\end{array}$ & $\begin{array}{l}\mathrm{NO}_{3}^{-}-\mathrm{N} \\
\left(\mathrm{mg} \mathrm{kg}^{-1}\right)\end{array}$ & $\begin{array}{l}\mathrm{NH}_{4}^{+}-\mathrm{N} \\
\left(\mathrm{mg} \mathrm{kg}^{-1}\right)\end{array}$ \\
\hline Ungrazed & $7.19 a$ & $14.3 a$ & $1.00 \mathrm{~b}$ & $28.0 \mathrm{a}$ & $1.63 a$ & $17.0 \mathrm{a}$ & $5.4 \mathrm{~b}$ & $199 b$ & $42.5 b$ & $3.5 b$ \\
\hline Grazed & $7.04 b$ & $7.6 b$ & $1.54 a$ & $14.7 b$ & $0.80 \mathrm{~b}$ & $9.8 \mathrm{~b}$ & $9.3 a$ & $230 a$ & $54.6 a$ & $4.9 a$ \\
\hline
\end{tabular}

Values are means of triplicate. Different lowercase letters indicate significant differences between two soil types at $P<0.05$ based on the analysis of variance. 
methane oxidation and $\mathrm{MOB}$ growth in the grassland soils compared to no and low urea amendments (Figs. 2a and 3). High $\mathrm{N}$ fertilization was shown to reduce methane oxidation in some unfertilized arable land [69], while no inhibition impact was observed in paddy soils receiving annual $\mathrm{N}$ fertilization [14, 15]. This discrepancy might be attributed to inherent properties of the soils used (soil texture, soil $\mathrm{N}$, and organic matter content), as those two studies were all carried out in paddy soils which received $\mathrm{N}$ fertilization annually [14, 15], whereas our present experiment was conducted in grassland soils under oligotrophic conditions (Table 1). Indeed, ammonia likely acted as the competitive inhibitor for MMO under the high urea treatment, as previously demonstrated [11]. Together, these results suggested that $\mathrm{N}$ was a trigger unlocking putative competition between methane and ammonia oxidation in global carbon and nitrogen cycling.

\section{Putative competition between active nitrifiers and MOB}

This study observed negative correlations between Methylobacter-like $\mathrm{MOB}$ and Nitrosospira lineage of $\mathrm{AOB}$, while strong and positive correlations between $\mathrm{AOB}$ and $\mathrm{NOB}$ in both ungrazed and grazed soils (Fig. 8). Methylobacter was the most responsive MOB in all the microcosms regardless of urea levels (Figs. 6a, b, 7a, b), indicating the competitive life strategy of Methylobacter [67]. Similarly, Nitrosospira species dominated $\mathrm{AOB}$ communities and were ubiquitous in all treatments (Figs. 6c, d, 7c, d). Strong positive links could be attributed to niche overlap and cross-feeding, while negative relationships could be attributed to competition and amensalism [70]. The strong negative correlations between Methylobacter-like MOB and Nitrosospira lineage of $A O B$ suggest the putative competitive relationships between these two critical players of soil $\mathrm{C}$ and $\mathrm{N}$ cycling competing for $\mathrm{N}$ or even for oxygen in the soils [14]. The strong and positive correlations between $\mathrm{AOB}$ and $\mathrm{NOB}$ suggested putative syntrophic relationships between those nitrifiers, as the nitrite produced by $A O B$ is a substrate for NOB [71].

In the ungrazed control soils, strong negative relationships occurred between Methylobacter and both Nitrosospira and Nitrosococcus (Fig. 8a). In the grazed soils, the putative competitive relationships between $\mathrm{MOB}$ and $\mathrm{AOB}$ exclusively occurred between Methylobacter and Nitrosospira (Fig. 8b). These results indicated that the network in ungrazed soils incorporated a substantially higher number of significant correlations than that in grazed soils. Previous study pointed out that grazing weakened the correlations between soil micro-food webs and ecosystem functions (soil $\mathrm{C}$ and $\mathrm{N}$ mineralization) [72]. To the best of our knowledge, the present study is the first work to reveal the impact of grazing on putative competition between active methanotrophs and nitrifiers. We did not directly analyze the interactions of one group upon another, and between the taxonomic groups and process rates. In addition, some important controls (e.g., $\mathrm{UO}+{ }^{12} \mathrm{CH}_{4}, \mathrm{UO}+{ }^{12} \mathrm{CO}_{2}, \mathrm{UO}+{ }^{13} \mathrm{CO}_{2}$ ) should be taken into consideration for further studies targeting the active methanotrophs and nitrifiers under $\mathrm{N}$ gradient. Nonetheless, our study unraveled the putative competitive relationships between active $M O B$ and $A O B$ based on the abundance, activity, composition, and network analysis of the functional genes. These results suggest that grazing decreases methane and ammonia oxidation activity, and diversity of nitrifiers as well as methanotrophs, and subsequently weakens the putative competitive relationships between methanotrophs and nitrifiers in grassland soils.

\section{CONCLUSIONS}

In this study, we linked the activity, composition, and potential relationships between active methanotrophs and nitrifying communities using stable-isotope techniques. Methylobacter lineage of MOB and Nitrosospira lineage of $\mathrm{AOB}$ were the dominating active methane and ammonia oxidizing microorganisms, respectively, in ungrazed and grazed soils, and Nitrosococcus and Nitrosomonas lineages of AOB were also involved in ammonia oxidation in ungrazed soils. The diversities of active $\mathrm{MOB}$ and $\mathrm{AOB}$ communities were higher in ungrazed than in grazed soils. And the network of co-occurring active phylotypes of $\mathrm{MOB}, \mathrm{AOB}$, and $\mathrm{NOB}$ was also more complex in ungrazed than in grazed soils, while the methane and ammonia oxidation activities were higher in ungrazed than in grazed soils. Therefore, these results suggest that grazing decreased diversity of active microbes mediated in $\mathrm{C} / \mathrm{N}$ cycling, thus suppressing both methane oxidation and nitrification activity, weakening their putative competitive relationships, and thereby increasing methane emissions. These studies will help to understand the complex biotransformation processes of $\mathrm{C}$ and $\mathrm{N}$, which are important for development of management practices to mitigate greenhouse-gas emissions in grassland soils.

\section{REFERENCES}

1. Cheng W, Yagi K, Xu H, Sakai H, Kobayashi K. Influence of elevated concentrations of atmospheric $\mathrm{CO}_{2}$ on $\mathrm{CH}_{4}$ and $\mathrm{CO}_{2}$ entrapped in rice-paddy soil. Chem Geol. 2005;218:15-24.

2. Koka JK. Gas phase activation activation of methane methane molecule molecule with lead lead benzene benzene dication dication complex complex ionion, $[\mathrm{Pb}$ (Benzene) $\left.)_{2}\right]^{2+}$. Mater Sci Appl. 2019;10:105-17.

3. Pratscher J, Vollmers J, Wiegand S, Dumont MG, Kaster AK. Unravelling the identity, metabolic potential and global biogeography of the atmospheric methane-oxidizing upland soil cluster a. Environ Microbiol. 2018;20:1016-29.

4. Kalyuzhnaya MG, Gomez OA, Murrell JC. The methane-oxidizing bacteria (methanotrophs). In: Taxonomy, genomics and ecophysiology of hydrocarbondegrading microbes, 2019; p. 245-78.

5. Hanson RS, Hanson TE. Methanotrophic bacteria. Microbiol Mol Biol R. 1996;60:439-71.

6. Holmes AJ, Costello A, Lidstrom ME, Murrell JC. Evidence that participate methane monooxygenase and ammonia monooxygenase may be evolutionarily related. FEMS Microbiol Lett. 1995;132:203-8.

7. Tavormina PL, Orphan VJ, Kalyuzhnaya MG, Jetten MS, Klotz MG. A novel family of functional operons encoding methane/ammonia monooxygenase-related proteins in gammaproteobacterial methanotrophs. Env Microbiol Rep. 2011;3:91-100.

8. Hatzenpichler RS. Identification and characterization of novel ammonia-oxidizing archaea and bacteria. Doctoral dissertation, Uniwien; 2011.

9. Jones RD, Morita RY. Methane oxidation by Nitrosococcus oceanus and Nitrosomonas europaea. Appl Environ Microbiol. 1983;45:401-10.

10. O'neill JG, Wilkinson JF. Oxidation of ammonia by methane-oxidizing bacteria and the effects of ammonia on methane oxidation. Microbiology. 1977;100:407-12.

11. Stein LY, Roy R, Dunfield PF. Aerobic methanotrophy and nitrification: processes and connections. In: Battista J (ed) Encyclopedia of life sciences (eLS). Wiley, Chichester. 2012. www.els.net. https://doi.org/10.1002/9780470015902.a0022213.

12. Daebeler A, Bodelier PL, Yan Z, Hefting MM, Jia Z, Laanbroek HJ. Interactions between Thaumarchaea, Nitrospira and methanotrophs modulate autotrophic nitrification in volcanic grassland soil. ISME J. 2014;8:2397-410.

13. Kou Y, Li J, Wang Y, Li C, Tu B, Yao M, et al. Scale-dependent key drivers controlling methane oxidation potential in Chinese grassland soils. Soil Biol Biochem. 2017;111:104-14.

14. Zheng $Y$, Huang R, Wang B, Bodelier PLE, Jia Z. Competitive interactions between methane-and ammonia-oxidizing bacteria modulate carbon and nitrogen cycling in paddy soil. Biogeosciences. 2014;11:3353-68.

15. Bodelier PL, Hahn AP, Arth IR, Frenzel P. Effects of ammonium-based fertilisation on microbial processes involved in methane emission from soils planted with rice. Biogeochemistry. 2000;51:225-57.

16. Bodelier PL, Roslev P, Henckel T, Frenzel P. Stimulation by ammonium-based fertilizers of methane oxidation in soil around rice roots. Nature. 2000;403:421-4.

17. Krüger $\mathrm{M}$, Frenzel $\mathrm{P}$. Effects of $\mathrm{N}$-fertilisation on $\mathrm{CH}_{4}$ oxidation and production, and consequences for $\mathrm{CH}_{4}$ emissions from microcosms and rice fields. Global Change Biol. 2003;9:773-84.

18. Rime T, Niklaus PA. Spatio-temporal dynamics of soil $\mathrm{CH}_{4}$ uptake after application of $\mathrm{N}$ fertilizer with and without the nitrification inhibitor 3, 4-dimethylpyrazole phosphate (DMPP). Soil Biol Biochem. 2017;104:218-25.

19. Van Zwieten $L$, et al. Biochar effects on nitrous oxide and methane emissions from soil. In: Biochar for environmental management. Routledge; 2015. p. 521-52.

20. Kravchenko IK. Methane oxidation in boreal peat soils treated with various nitrogen compounds. Plant Soil. 2002;242:157-62. 
21. Mutschlechner M, Praeg N, Illmer P. The influence of cattle grazing on methane fluxes and engaged microbial communities in alpine forest soils. FEMS Microbiol Ecol. 2018;94:fiy019.

22. Mishra VK, Shukla R, Shukla PN. Inhibition of soil methane oxidation by fertilizer application: an intriguing but persistent paradigm. EPP. 2018;3:57-69.

23. Wright AL, Hons FM, Rouquette JrFM. Long-term management impacts on soil carbon and nitrogen dynamics of grazed bermudagrass pastures. Soil Biol Biochem. 2004;36:1809-16.

24. Wang $Y$, Xue $M$, Zheng $X$, Ji B, Du R, Wang Y. Effects of environmental factors on $\mathrm{N}_{2} \mathrm{O}$ emission from and $\mathrm{CH}_{4}$ uptake by the typical grasslands in the Inner Mongolia. Chemosphere. 2005;58:205-15.

25. Allen-Dias B. Rangelands in a changing climate: impacts, adaptations and mitigation. In: Watson, RT, et al. (Eds.), Climate change 1995. Impacts, adaptations and mitigation of climate change: scientific-technical analyses. Cambridge University Press, Cambridge, Published for the Intergovernmental Panel on Climate Change; 1996. p.131-58

26. Pineiro G, Paruelo JM, Oesterheld M. Potential long-term impacts of livestock introduction on carbon and nitrogen cycling in grasslands of Southern South America. Global Change Biol. 2006;12:1267-84.

27. Shi $\mathrm{H}$, Hou L, Yang L, Wu D, Zhang L, Li L. Effects of grazing on $\mathrm{CO}_{2}, \mathrm{CH}_{4}$, and $\mathrm{N}_{2} \mathrm{O}$ fluxes in three temperate steppe ecosystems. Ecosphere. 2017;8:e01760.

28. Wang X, Zhang Y, Huang D, Li Z, Zhang X. Methane uptake and emissions in a typical steppe grazing system during the grazing season. Atmos Environ. 2015;105:14-21.

29. Tang S, Zhang Y, Zhai X, Wilkes A, Wang C, Wang K. Effect of grazing on methane uptake from Eurasian steppe of China. BMC Ecol. 2018;18:11.

30. Li Y, Liu Y, Pan H, Hernández M, Guan X, Wang W, et al. Impact of grazing on shaping abundance and composition of active methanotrophs and methane oxidation activity in a grassland soil. Biol Fert Soils. 2020;56:1-12.

31. Pan H, Xie K, Zhang Q, Jia Z, Xu J, Di H, et al. Archaea and bacteria respectively dominate nitrification in lightly and heavily grazed soil in a grassland system. Biol Fert Soils. 2018;54:1-14

32. Lampurlanés J, Cantero-Martinez C. Soil bulk density and penetration resistance under different tillage and crop management systems and their relationship with barley root growth. Agron J. 2003;95:526-36.

33. Kalembasa SJ, Jenkinson DS. A comparative study of titrimetric and gravimetric methods for the determination of organic carbon in soil. J Sci Food Agr. 1973;24:1085-90.

34. Olsen SR. Estimation of available phosphorus in soils by extraction with sodium bicarbonate. US Department of Agriculture; 1954.

35. Zhao Y, Zhang L, Chen Y, Liu X, Xu W, Pan Y, et al. Atmospheric nitrogen deposition to China: a model analysis on nitrogen budget and critical load exceedance. Atmos Environ. 2017;153:32-40.

36. Whitehead DC. Sources and transformations of organic nitrogen in intensively managed grassland soils//nitrogen fluxes in intensive grassland systems. Springer, Dordrecht; 1986. p. 47-58.

37. Magoč T, Salzberg SL. FLASH: fast length adjustment of short reads to improve genome assemblies. Bioinformatics. 2011;27:2957-63.

38. Tamura K, Stecher G, Peterson D, Filipski A, Kumar S. MEGA6: molecular evolutionary genetics analysis version 6.0. Mol Biol Evol. 2013;30:2725-9.

39. Smets W, Leff JW, Bradford MA, McCulley RL, Lebeer S, Fierer N. A method for simultaneous measurement of soil bacterial abundances and community composition via 16S rRNA gene sequencing. Soil Biol Biochem. 2016:96:145-51.

40. Wang JC, Li Y, Li GY, Xiao Y, Li WM, Ma Q, et al. Simultaneous measurement of bacterial abundance and composition in response to biochar in soybean field soil using 16S rRNA gene sequencing. Land Degrad Dev. 2018;29:2172-82.

41. Stämmler F, Gläsner J, Hiergeist A, Holler E, Weber D, Oefner PJ, et al. Adjusting microbiome profiles for differences in microbial load by spike-in bacteria. Microbiome. 2016:4:1-13.

42. Bastian M, Heymann S, Jacomy M. Gephi: An open source software for exploring and manipulating networks. ICWSM. 2009;8:361-2.

43. Tang $S$, Wang $K$, Xiang $Y$, Tian D, Wang J, Liu Y, et al. Heavy grazing reduces grassland soil greenhouse gas fluxes: a global meta-analysis. Sci Total Environ. 2019;654:1218-24.

44. Pan $\mathrm{H}$, Ying S, Liu H, Zeng L, Zhang Q, Liu Y, et al. Microbial pathways for nitrous oxide emissions from sheep urine and dung in a typical steppe grassland. Biol Fert Soils. 2018;54:717-30.

45. Wolf B, Zheng X, Brüggemann N, Chen W, Dannenmann M, Han X, et al. Grazinginduced reduction of natural nitrous oxide release from continental steppe. Nature. 2010;464:881-4.

46. Hansen $\mathrm{S}$, Maehlum JE, Bakken LR. $\mathrm{N}_{2} \mathrm{O}$ and $\mathrm{CH}_{4}$ fluxes in soil influenced by fertilization and tractor traffic. Soil Biol Biochem. 1993;25:621-30.

47. Ruser $R$, Schilling $R$, Steind $H_{\text {, Flessa } H}$, Beese F. Soil compaction and fertilization effects on nitrous oxide and methane fluxes in potato fields. Soil Sci Soc Am J. 1998;62:1587-95.
48. Sitaula BK, Hansen S, Sitaula JIB, Bakken LR. Effects of soil compaction on $\mathrm{N}_{2} \mathrm{O}$ emission in agricultural soil. Chemosphere-Glob Change Sci.2000;2:367-71.

49. Priemé A, Christensen S. Methane uptake by a selection of soils in Ghana with different land use. J Geophys Res Atmos. 1999;104:23617-22.

50. Saggar S, Hedley CB, Giltrap DL, Lambie SM. Measured and modelled estimates of nitrous oxide emission and methane consumption from a sheep-grazed pasture. Agr Ecosyst Environ. 2007;122:357-65.

51. Cardoso AS, et al. 0653 Grazing intensities and season affect $\mathrm{N}_{2} \mathrm{O}$ emissions in a tropical pastureland. J Anim Sci. 2016;94:312-312. suppl_5.

52. Yin M, Gao X, Tenuta M, Li L, Gui D, Li X, et al. Enhancement of $\mathrm{N}_{2} \mathrm{O}$ emissions by grazing is related to soil physicochemical characteristics rather than nitrifier and denitrifier abundances in alpine grassland. Geoderma. 2020;375:114511.

53. Li K, Gong Y, Song W, Lv J, Chang Y, Hu Y, et al. No significant nitrous oxide emissions during spring thaw under grazing and nitrogen addition in an alpine grassland. Global Change Biol. 2012;18:2546-54.

54. Jia Z, Conrad R. Bacteria rather than Archaea dominate microbial ammonia oxidation in an agricultural soil. Environ Microbiol. 2009;11:1658-71.

55. Pratscher J, Dumont MG, Conrad R. Ammonia oxidation coupled to $\mathrm{CO}_{2}$ fixation by archaea and bacteria in an agricultural soil. Proc Natl Acad Sci USA. 2011;108:4170-5.

56. Hink L, Gubry-Rangin C, Nicol GW, Prosser Jl. The consequences of niche and physiological differentiation of archaeal and bacterial ammonia oxidisers for nitrous oxide emissions. ISME J. 2018;12:1084-93.

57. Fu TC, Lin YC, Chang CM, Chou WL, Yuan PH, Liu MH, et al. Management practices have a major impact on nitrifier and denitrifier communities in a semiarid grassland ecosystem. J Soil Sediment. 2016;16:896-908.

58. Gubry-Rangin C, Nicol GW, Prosser Jl. Archaea rather than bacteria control nitrification in two agricultural acidic soils. FEMS Microbiol Ecol. 2010;74: 566-74.

59. Lu L, Jia Z. Urease gene-containing Archaea dominate autotrophic ammonia oxidation in two acid soils. Environ Microbiol. 2013;15:1795-809.

60. Clark DR, McKew BA, Dong LF, Leung G, Dumbrell AJ, Stott A, et al. Mineralization and nitrification: archaea dominate ammonia-oxidising communities in grassland soils. Soil Biol Biochem. 2020;143:107725.

61. Huang R, Wang Y, Gao X, Liu J, Wang Z, Gao M. Nitrous oxide emission and the related denitrifier community: a short-term response to organic manure substituting chemical fertilizer. Ecotox Environ Safe. 2020;192:110291.

62. Webster G, Embley TM, Freitag TE, Smith Z, Prosser Jl. Links between ammonia oxidizer species composition, functional diversity and nitrification kinetics in grassland soils. Environ Microbiol. 2005;7:676-84

63. Taylor AE, Bottomley PJ. Nitrite production by Nitrosomonas europaea and Nitrosospira sp. AV in soils at different solution concentrations of ammonium. Soil Biol Biochem. 2006;38:828-36

64. Shaw LJ, Nicol GW, Smith Z, Fear J, Prosser Jl, Baggs EM. Nitrosospira spp. can produce nitrous oxide via a nitrifier denitrification pathway. Environ Microbiol. 2006;8:214-22.

65. Koch $H$, van Kessel MA, Lücker S. Complete nitrification: insights into the ecophysiology of comammox Nitrospira. Appl Microbiol Biot. 2019;103: 177-89.

66. Kits KD, Jung MY, Vierheilig J, Pjevac P, Sedlacek CJ, Liu S, et al. Low yield and abiotic origin of $\mathrm{N}_{2} \mathrm{O}$ formed by the complete nitrifier Nitrospira inopinata. Nat Commun. 2019;10:1-12.

67. Ho A, Kerckhof FM, Luke C, Reim A, Krause S, Boon N, et al. Conceptualizing functional traits and ecological characteristics of methane-oxidizing bacteria as life strategies. Environ Microbiol Rep. 2013;5:335-45.

68. Semrau JD, DiSpirito AA, Yoon S. Methanotrophs and copper. FEMS Microbiol Rev. 2010;34:496-531.

69. Mosier A, Schimel D, Valentine D, Bronson K, Parton W. Methane and nitrous oxide fluxes in native, fertilized and cultivated grasslands. Nature. 1991;350:330-2.

70. Faust K, Raes J. Microbial interactions: from networks to models. Nat Rev Microbiol. 2012;10:538-50.

71. Daims $H$, Lücker $S$, Wagner M. A new perspective on microbes formerly known as nitrite-oxidizing bacteria. Trends Microbiol. 2016;24:699-712.

72. Wang B, Wu L, Chen D, Wu Y, Hu S, Li L, et al. Grazing simplifies soil micro-food webs and decouples their relationships with ecosystem functions in grasslands. Global Change Biol. 2020;26:960-70.

\section{ACKNOWLEDGEMENTS}

This work was financially supported by Natural Science Foundation of China (41977033, 41907026, and 41721001), Fundamental Research Funds for the Central Universities (2019QNA6011), National Key Basic Research Program of China (2014CB138801), Shandong Provincial Natural Science Foundation (ZR2019BD032), China Postdoctoral Science Foundation (2020T130387 and 2019M652448). CG-R was 
12

funded by a Royal Society University Research Fellowship (UF150571). Special thanks to ChunMei Meng, Yu Luo, and Yan Zheng for their assistance in laboratory analyses.

\section{AUTHOR CONTRIBUTIONS}

$H P, Y L$, and $C G-R$ conceived and designed the project. HP performed the research. YWL and CYL assisted with sample collection. HP and HJF analyzed the data and created the figures. HP wrote the manuscript. YL, ZJJ, YPZG, QCZ, CXT, JMX, HJD, and CG-R revised the paper. All authors discussed and interpreted the data and contributed to the manuscript. All authors read and approved the final manuscript.

\section{COMPETING INTERESTS}

The authors declare no competing interests.

\section{ADDITIONAL INFORMATION}

Supplementary information The online version contains supplementary material available at https://doi.org/10.1038/s43705-021-00068-2.

Correspondence and requests for materials should be addressed to Cécile GubryRangin or Yong Li.
Reprints and permission information is available at http://www.nature.com/ reprints

Publisher's note Springer Nature remains neutral with regard to jurisdictional claims in published maps and institutional affiliations.

Open AccessThis article is licensed under a Creative Commons Attribution 4.0 International License, which permits use, sharing, adaptation, distribution and reproduction in any medium or format, as long as you give appropriate credit to the original author(s) and the source, provide a link to the Creative Commons licence, and indicate if changes were made. The images or other third party material in this article are included in the article's Creative Commons licence, unless indicated otherwise in a credit line to the material. If material is not included in the article's Creative Commons licence and your intended use is not permitted by statutory regulation or exceeds the permitted use, you will need to obtain permission directly from the copyright holder. To view a copy of this licence, visit http://creativecommons. org/licenses/by/4.0/.

(c) The Author(s) 2021, corrected publication 2022 